\title{
Alkaloids of Linderae Radix suppressed the lipopolysaccharide-induced expression of cytokines in cultured macrophage RAW 264.7 cells
}

David Jiyao Chou ${ }^{1}$, Kelly Yinching Lam ${ }^{1}$, Jianping Chen ${ }^{1}$, Ping Yao ${ }^{1}$, Tina Tingxia Dong ${ }^{1}$, Aizhen Xiong ${ }^{2}$, Guixin $\mathrm{Chou}^{2}$, Zhengtao Wang ${ }^{2}$, Karl Wah-Keung Tsim,

${ }^{l}$ Division of Life Science and Center for Chinese Medicine, The Hong Kong University of Science and Technology, Hong Kong, China; ${ }^{2}$ Institute of Chinese Materia Medica, Shanghai University of Traditional Chinese Medicine, Shanghai, China

\begin{abstract}
Linderae Radix, the dry roots of Lindera aggregata (Sims) Kosterm, has long been used as traditional Chinese medicine for treatment of inflammatory diseases. The total alkaloids are believed to be the active components responsible for anti-inflammation of Linderae Radix. Here, the total alkaloids of Linderae Radix were extracted and isolated, including 12 isoquinoline alkaloids and 1 furan sesquiterpene. Within the alkaloids, norisoboldine, boldine, linderaline, isoboldine, reticuline, N-methyllaurotetanine, norjuziphine were found to be the major ingredients. In lipopolysaccharide-treated macrophage RAW 264.7 cells, application of Linderae Radix extract, or total alkaloids, suppressed the transcription of proinflammatory cytokines, interleukin- $1 \beta$ and interleukin-6. Out of the 12 alkaloids, norisoboldine, boldine, and isoboldine were tested in lipopolysaccharide-treated macrophages, and norisoboldine was the strongest alkaloid in suppressing the cytokine expressions. The current studies suggested that the identification of alkaloids from Linderae Radix could provide a plausible explanation for herbal therapeutic functions.
\end{abstract}

Keywords traditional Chinese medicine, Linderae Radix, total alkaloids, isoquinoline alkaloids, proinflammatory cytokines

\section{INTRODUCTION}

Inflammation is a complex non-specific response of innate immunity, which is responsible for fighting against harmful stimulus, such as pathogens, damaged cells, and irritants (Ferrero-Miliani et al., 2007). Rheumatoid arthritis is a kind of common auto-immune disease of joint inflammatio $\mathrm{n}$ :the pathogenesis of this synovial inflammation occurs through the irreversible damage of articular cartilage and destruction of underlying joint (Grainger and Rowbotham, 2013;Tak and Bresnihan, 2000). During the inflammation on synovium, the articular structures are destroyed by the aggressive joint lining, and the synovium is being infiltrated with $\mathrm{T}$ cells, $\mathrm{B}$ cells and macrophages. The inflammatory process of rheumatoid arthritis is initialized by stimulation of exogenous or endogenous antigens on synovial cells (Scott et al., 2010). Of which, macrophages are activated to overexpress pro-inflammatory cytokines, e.g. interleukin-6 (IL-6) and IL-1 $\beta$; these cytokines elevate the catabolic process of cartilage cells via a NF- $\kappa \mathrm{B}$ signaling pathway (Marok et al., 1996). The activation of catabolic cascade is able to induce the secretion of matrix metalloproteinases (MMPs) and to degrade the extra-cellular matrix of cartilage (Bresnihan, 1999; Mix et

*Correspondence: Karl Wah-Keung Tsim

E-mail: botsim@ust.hk

Received April 14, 2014; Accepted November 10, 2014; Published

November 30, 2014

doi: http://dx.doi.org/10.5667/tang.2014.0019

(C)2014 by Association of Humanitas Medicine

This is an open access article under the CC BY-NC license.

(http://creativecommons.org/licenses/by-nc/3.0/) al., 2001). In this scenario, the blockade of pro-inflammat ory cytokines is clinically relevant with potential targets fo $r$ the therapy of rheumatoid arthritis (Feldmann and Maini, 2008).

Linderae Radix, the dry root of Lindera aggregata (Sims) Kosterm, is a well-known traditional Chinese medicine(TCM) used in the treatment of chest and abdomen pain, indigestion, regurgitation, cold hernia and frequent urination (Chou et al., 1998). The biological properties of alkaloid from Linderae Radix had been demonstrated of having anti-microbial, analgesic and anti-inflammatory ( $\mathrm{Li}$ et al., 1997). Indeed, norisoboldine, linderaline, isoboldine, reticuline, N-methyllaurotetanine and norjuziphine are the main constituents in the alkaloids of Linderae Radix. Here, a biological screening of Linderae Radix alkaloids was aiming to find novel potential agents in inhibiting the pro-inflammatory cytokines against rheumatic inflammation.

\section{MATERIALS AND METHODS}

Plant materials

Linderae Radix, the dry roots of Lindera aggregata (Sims) Kosterm, was acquired from Hong Kong market in November of 2011, and the herb authenticity was identified by one of the authors Dr. Tina Dong. The voucher specimens (WYS001-006) were deposited in Centre for Chinese Medicine at Hong Kong University of Science \& Technology.

Extraction and isolation of herbal materials 


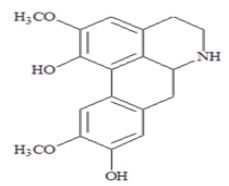

Norisoboldine

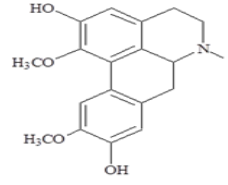

Boldine

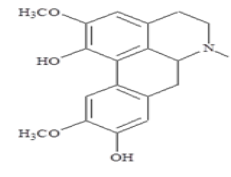

Isoboldine

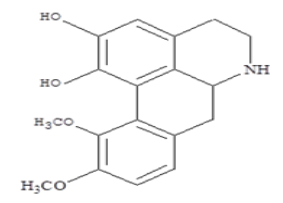

Linderaline

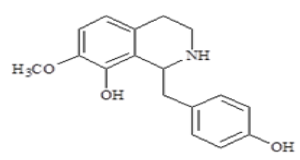

Norjuziphine

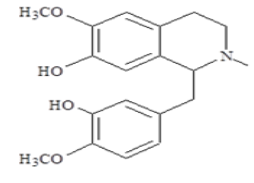

Reticuline

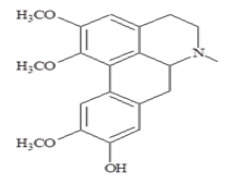

N-methyllaurotetanine
Fig. 1. Chemical structures of major isolated products from total a lkaloids. The structures were identified by comparing their ESI-M $\mathrm{S},{ }^{1} \mathrm{H}-\mathrm{NMR}(400 / 500 \mathrm{MHz})$ and ${ }^{13} \mathrm{C}-\mathrm{NMR}(100 / 125 \mathrm{MHz})$ data. The identity of these chemicals have been reported in literatures. Due to the same functional group -- isoquionline in all alkaloids, they were called isoquinoline alkaloids (Chou et al., 2005). The ${ }^{1}$ $\mathrm{H},{ }^{13} \mathrm{C}$-spectra and ESI-MS spectra are shown in Appendix.

For the ethanol extraction, eight $\mathrm{kg}$ Linderae Radix powder were extracted by 55\% ethanol, and refluxed for 2 hours, three times. The solvent was evaporated to give dark viscous extracts (Fig. 1S). Then, 2\% hydrochloric acid was used for acid dissolution of alkaloids. The precipitation of total alkaloids was generated from alkaline precipitation by dropping $10 \%$ sodium hydroxide to adjust the $\mathrm{pH}$ value to 9.0 and lyophilizing at 0.02 mbar, $-52^{\circ} \mathrm{C}$. The powder of total alkaloids was then eluted with solvent system composed of dichloromethane and methanol in silica gel column to obtain four fractions (fraction A to D). Fraction A was subjected to silica gel column eluted with petroleum ether and ethyl acetate (6:1) to yield linderane; Fraction B was subjected to silica gel high performance column eluted with dichloromethane and methanol (10:1 to 5:1), then separated by MCI-gel CHP 20P column eluted with methanol and water (3:7 to 100:0) to generate 2 fractions, B-1 and B-2. B-1 was purified by Sephadex LH-20 column with methanol to yield isoboldine and reticuline (Xiao et al., 2004; Yu et al., 2003). And B-2 was chromatographed by silica gel high performance column eluted with dichloromethane and methanol (10:1 to 5:1) to form N-methyllaurotetanine (Zhu et al., 2007). The yellow powder was then purified by prep HPLC on YMC RP-18 column eluted with methanol and water (4:6 to 9:1) to give actinodaphnine and pallidine (Guinaudenu et al., 1979; Xiao et al., 2006); Fraction C was eluted by silica gel high performance column with dichloromethane and methanol (5:1 to 1:1) to give 3 fractions, C-1, C-2 and C-3. C-1 was then applied to Sephadex LH-20 column with methanol repeatedly to yield norisoboldine and lindcarpine (Rachmatiah et al., 2009). C-2 was subjected to silica gel column eluted with dichloromethane and methanol $(5: 1$ to $1: 1)$ to yield boldine and linderaline (Chou et al., 2005; Xiao et al., 2004). C-3 was purified by Sephadex LH-20 column with methanol and recrystallized with dichloromethane and methanol (3:1) to generate norjuziphine (El-Kawi et al., 1984); Fraction D was then decolorized and eluted by MCI-gel column with methanol and water (4:6 to 7:3) to give secoboldine and secolaurolitsine

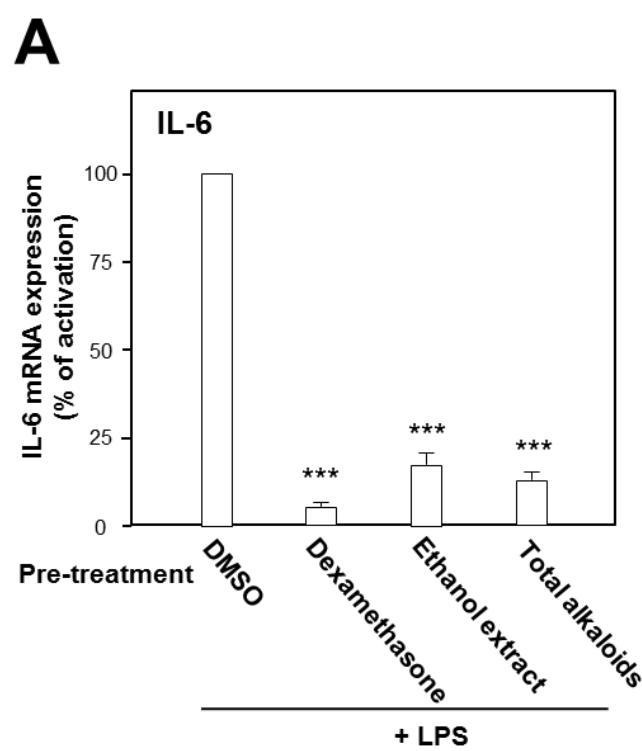

B

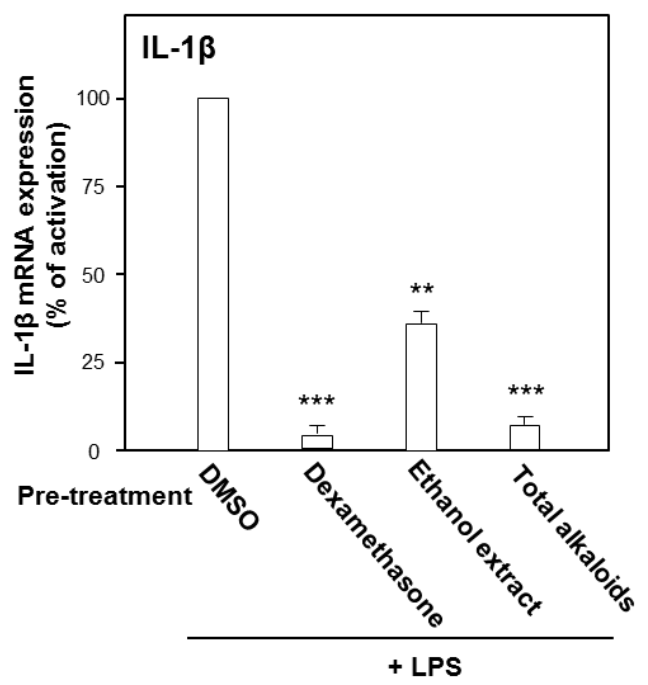

Fig. 2. Effects of ethanol extract and total alkaloids from Lindera Radix on mRNA expression of LPS-induced cytokines on macrophage cells. Macrophage RAW 264.7 cells were pre-treated with $30 \mu \mathrm{g} / \mathrm{ml}$ of the ethanol extract or total alkaloids, respectively. Dexamethasone at 30 $\mu \mathrm{M}$ was selected as positive control. After 3 hours of the treatment, LPS $(0.1 \mu \mathrm{g} / \mathrm{ml})$ was applied. Then, the cultured cells were incubated for 20 hours, and the mRNA expression of IL-6 (A) and IL-1 $\beta$ (B) were detected by qPCR. GAPDH was used as the internal control. Values were expressed as the percentage of activation against negative control in Mean $\pm \mathrm{SD}, n=3$. " where $p<0.05,{ }^{* *}$ where $p<0.01$.

(Chiou et al., 1998; Milian et al., 2004) (Fig. 2S).

\section{Cell viability}

RAW 264.7, mouse macrophage cell line from American Type Culture Collection (ATCC, Manassas, VA), was maintained in culturing DMEM (Invitrogen, Carlsbad, CA) supplemented with $5 \%$ FBS (Invitrogen), $100 \mathrm{~g} / \mathrm{ml}$ penicillin and $100 \mathrm{~g} / \mathrm{ml}$ streptomycin (Invitrogen), at $37^{\circ} \mathrm{C}$ in a water saturated $5 \% \mathrm{CO}_{2}$ incubator. The viability of macrophage RAW 264.7 cells was measured by MTT assay. Cells were cultured in 96-well plate. After the treatment of isoquinoline alkaloids for 24 hours, MTT $(0.5 \mathrm{mg} / \mathrm{ml})$ was added into the cultures, then extracted by DMSO solvent. The absorbance at $570 \mathrm{~nm}$ was measured. The cell viability was calculated as the percentage of the absorbance 
value of negative control while the value of negative control was $100 \%$.

\section{Quantification of the mRNA expressions}

Macrophage RAW 264.7 cells were cultured in 6-well plate at a number of $2 \times 10^{5}$ cells per well in $5 \% \mathrm{CO}_{2}, 37^{\circ} \mathrm{C}$ atmosphere. After incubation for 24 hours, each isoquinoline alkaloid was pre-treated. And 3 hours later, LPS, the major ingredient on the membrane of Gram negative bacteria binding to Toll-like receptor-4 (TLR-4) on macrophage and promoting the gene expression of pro-inflammatory cytokines, was applied onto the cultures for 20 hours. Then, the cultured medium was discarded, and cells were collected and stored at $-80^{\circ} \mathrm{C}$ overnight (Du et al., 2013). The total RNA was isolated with RNAzol reagent (Molecule Research Center, Cincinnati, $\mathrm{OH}$ ) according to the manufacturer's protocol. Three $\mu \mathrm{g}$ total RNA extracted from cultured cells were then reversely transcribed by Moloney Murine Leukemia Virus (MMLV) reverse transcriptase kit (Invitrogen) with oligo-d(T) primer (Invitrogen) in a $20 \mu \mathrm{l}$ reaction. And quantitative real-time PCR was performed by Faststart Universal SYBR Green Master (ROX) (Roche Applied Science, Mannheim, Germany), according to the manufacturer's instructions. SYBR green signal was detected by 7500 Fast Real-Time PCR machine (Applied Biosystems, Brooklyn, NY). Calculation was done by using the $\mathrm{Ct}$ value of Glyceraldehyde 3-phosphate dehydrogenase (GAPDH) to normalize the $\mathrm{Ct}$ value of target gene in each sample to obtain first, which then deducted the $\Delta \mathrm{Ct}$ value of negative control to achieve the $\Delta \Delta \mathrm{Ct}$ value. (Winer et al., 1999). Transcription levels were then quantified by the percentage of activation compared with mRNA expression of LPS stimulation. PCR products were analyzed by gel electrophoresis on a $1.5 \%$ agarose gel, and the specificity of amplification was confirmed by melting curves. Primers employed in quantitative real-time PCR analysis were: 5' - GGA GTA CCA TAG CTA CCT GG-3' and 5'- CTA GGT TTG CCG AGT AGA TC-3' for murine IL-6 (283 bp; NM 031168); 5'- AAA TAC CTG TGG CCT TG-3' and 5'-TTA GGA AGA CAC GGA TTC-3' for murine IL-1 $\beta$ (296 bp; NM_008361); 5'-AGT GAC AAG CCT GTA GCC-3' and 5'-AGG TTG ACT TTC TCC TGG-3' for murine TNF- $\alpha$ (251 bp; NM_013693); 5' - AAC GGA TTT GGC CGT ATT GG-3' and 5'- CTT CCC GTT CAG CTC TGG G-3' for GAPDH (516 bp; L29427) used as internal control in all cases.

\section{Statistical analysis}

Statistical analysis (SPSS) was used to analyze the correlation of different bioactivity of isoquinoline alkaloids. Statistical tests were done by using one-way ANOVA. The data was separated into two groups to compare both the activation of tested compounds and control. The control group was varied in different experiments, and which was specified in the figure legends. Data were expressed as Means $\pm \mathrm{SD}$, where $n=3$. Statistically significant changes were classed as significant ["] where $p<0.05$, highly significant $\left[{ }^{* *}\right]$ where $p<0.01$ and highly significant $[* * *]$ where $\mathrm{p}<0.001$.

\section{Result}

Linderae Radix ( $8 \mathrm{~kg}$ ) was powdered and then extractedby methods, shown in Supporting information 1 (Fig. 1S).After lyophilization, the resulting precipitate of total alkaloids from Linderae Radix was $\sim 200$ g. Then, the total alkaloids were subjected to column chromatography by different solvents and elution, which was not described fully in here. The purification steps were summarized in Fig. $2 \mathrm{~S}$. The chemical structures for products with higher isolation yield including norisoboldine, boldine, linderaline, isoboldine, reticuline, Nmethyllaurotetanine, norjuziphine, were spectrally analyzed by ${ }^{1} \mathrm{H}$ and ${ }^{13} \mathrm{C}-\mathrm{NMR}$, shown in Fig. 1 and Appendix.

The growth of macrophage RAW 264.7 cells was explored to determine the cell number used in the following experiments The number of 10,000 cells per well was chosen to detect the viability under the treatment of the alkaloids. Before screening for bioactivities of alkaloids, the cytotoxicity of each alkaloid in RAW 264.7 cells was first performed by MTT assay in different concentrations. The results suggested that for each isoquinoline alkaloid, the doses below $30 \mu \mathrm{M}$ did not show remarkable cytotoxicity or proliferation effect. At $100 \mu \mathrm{M}$, the cytotoxicity was found. Thus, $30 \mu \mathrm{M}$ was recognized as the most applicable working concentration for alkaloids in the following experiments (Fig. 3S), which provided a critical reference on choosing the concentration of alkaloids.

Under the stimulation of LPS, the mRNA expressions of pro-inflammatory cytokines were measured by real-time PCR. LPS at concentration of $0.1 \mu \mathrm{g} / \mathrm{ml}$ was selected as the concentration for treatment of herbal extract and alkaloids. The ethanol extract, total alkaloids and seven alkaloids were applied onto the cultured cells. As shown in Fig. 2, the ethanol extract and the total alkaloids could substantially suppress the gene transcription levels of pro-inflammatory cytokines, IL-6 and IL-1 $\beta$, stimulated by LPS. The suppression on both cytokines was more robust in the treatment of total alkaloids than that of the ethanol extract, which could be revealed by over $80 \%$ of suppression (Fig. 2).

The role of individual alkaloid was tested in the cell model. At the largest working concentration $(30 \mu \mathrm{M})$, norisoboldine, boldine and isoboldine significantly reduced theLPS-enhanced mRNA expression of IL-6 (Fig. 3A). In addition, the expression of IL- $1 \beta$, induced by LPS, was suppressed by both applications of boldine and norisoboldine at $30 \mu \mathrm{M}$ (Fig. 3B). The other alkaloids did not show this suppression (data not shown). These results indicated that the ethanol extract, total alkaloids and few isoquinoline alkaloids from Linderae Radix showed inhibition against the LPS-enhanced gene expressions of proinflammatory cytokines, IL- 6 and IL- $\beta$, on mRNA levels. By comparing to the total alkaloids, individual alkaloids exerted limited or little effect on reducing gene transcription levels of IL-6 and IL-1 $\beta$ up-regulated by LPS, which suggested a possible synergistic effect of different alkaloids within Linderae Radix.

\section{DISCUSSION}

Rheumatoid arthritis is caused by a cascade of auto-immune disorder, which could induce cartilage damage and bone destruction. Owing to expensive costs of physical therapy and side effects of synthetic drug, the development of a costeffective and safe treatment of rheumatoid arthritis has been searched for many years. TCM has been well documented for their fewer side effects, and Chinese are very keen on this beneficial advantage for health care of various diseases. Therefore, herbal medicine might support a novel direction for the treatment of rheumatoid arthritis. Linderae Radix, a TCM used for alleviating pain and nourishing organs, was studied here for the purpose of a possible development of a drug candidate in treating rheumatoid arthritis. In LPS - induced RAW 264.7 cells, the ethanol extract and total alkaloids could dramatically decrease the enhanced mRNA expression of IL-6 and IL-1 $\beta$. In addition, the isoquinoline alakloids, including norisoboldine, boldine and isoboldine, displayed their 
A

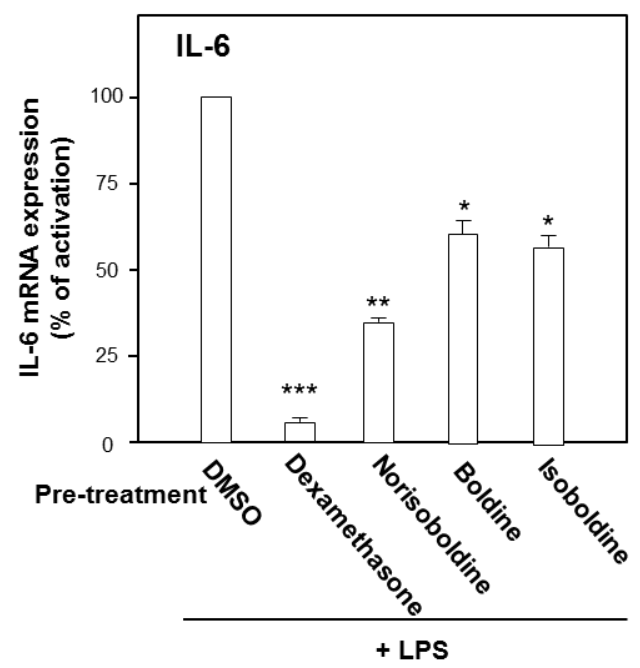

B

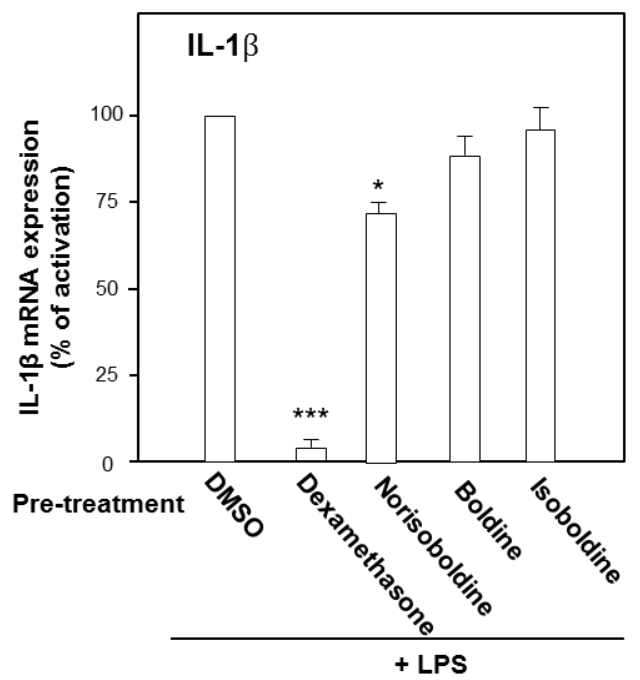

Fig. 3. Effects of three isoquinoline alkaloids on mRNA expression of LPS-induced cytokines on macrophage cells. Macrophage RAW 264.7 cells were pre-treated with $30 \mu \mathrm{M}$ of the alkaloids, e.q. norisoboldine, boldine, isoboldine. Dexamethasone at $30 \mu \mathrm{M}$ was selected as positive control. After 3 hours of the treatment, LPS $(0.1 \mu \mathrm{g} / \mathrm{ml})$ was applied. Then, the cultured cells were incubated for 20 hours, and the mRNA expression of IL-6 (A) and IL-1 $\beta$ (B) were detected by qPCR. GAPDH was used as the internal control. Values were expressed as the percentage of activation against negative control in Mean $\pm \mathrm{SD}, n=3$. where $p<0.05,{ }^{* *}$ where $p<0.01$.

inhibition on the LPS - stimulated mRNA levels of those proinflammatory cytokines.

Norisoboldine, boldine and isoboldine might be the effective components in alkaloids deriving from Linderae Radix. The findings indicated that both herbal extract and alkaloids from Linderae Radix might inhibit the LPS-induced IL- 6 and IL- $1 \beta$ by blocking the phosphorylation of NF- $\kappa$ B subunits. As a result, the gene expression of pro-inflammatory mediators would be reduced, which would then prohibit the catabolic process of chondrocytes to produce MMPs. Thus, the reduction of destroying cartilage matrix caused by MMPs would potentially facilitate the therapy of rheumatoid arthritis.
However, the ethanol extract and total alkaloids showed better effect in the down-regulation of pro-inflammatory cytokines stimulated by LPS, suggesting a possible synergistic role of different alkaloids. Furthermore, other alkaloids that had not been isolated yet might exist in the herbal medicine with antiinflammatory effects via suppressing LPS-enhanced cytokines. Nevertheless, this study provided a plausible explanation for the therapeutic potency of alkaloids from Linderae Radix on anti-rheumatoid arthritis.

Total alkaloids and norisoboldine, derived from Linderae Radix, were demonstrated to prevent the production of LPSinduced mediators of inflammation in RAW 264.7 cells dosedependently by the suppression on NF- $\mathrm{BB}$ and MAPKs signaling pathways (Luo et al., 2009; Luo et al., 2010). Our results are in line to the previous results that the addition of boldine and isoboldine were considered as the active ingredient of Linderae Radix. The amount of norisoboldine ( 1\% of total alkaloids) in the herb is much higher than that of boldine and isoboldine $(\sim 0.05 \%$ and $\sim 0.035 \%$, respectively of total alkaloids). Under this scenario, norisoboldine should be the key alkaloid in triggering this cytokine suppression. Thus, Linderae Radix or its alkaloids could be further developed as the possible candidates of therapeutic agents against rheumatoid arthritis.

\section{ACKNOWLEDGEMENTS}

This research was supported by the grants of the project of Hong Kong Chinese Materia Medica Standards by Hong Kong government; Research Grants Council Theme-based Research Scheme (T13-607/12R), GRF (662911, 663012, 662713), The Hong Kong Jockey Club Charities Trust and Foundation of The Awareness of Nature (TAON12SC01) to Karl Tsim.

\section{CONFLICT OF INTEREST}

The authors declare no conflict of interest.

\section{REFERENCES}

Bresnihan B. Pathogenesis of joint damage in rheumatoid arthritis. J Rheumatol. 1999;26:717-719.

Chiou CM, Kang JJ, Lee SS. Litebamine N-homologues: preparation and anti-acetylcholinesterase activity. J Nat Prod. 1998;61:46-50.

Chou, GX, Nakamura, N, Ma, CM, Wang, ZT, Hattori, M. Isoquinoline alkaloids from Lindera aggregata. Chin J Nat Med. 2005;3:272-275.

Du CY, Choi RC, Zheng KY, Dong TT, Lau DT, Tsim KW. Yu Ping Feng San, an Ancient Chinese Herbal Decoction Containing Astragali Radix, Atractylodis Macrocephalae Rhizoma and Saposhnikoviae Radix, Regulates the Release of Cytokines in Murine Macrophages. PLoS One. 2013;8:e78622.

El-Kawi MA, Slatkin DJ, Schiff PL Jr, Dasgupta S, Chattopadhyay SK, Ray AB. Additional alkaloids of Pachygone ovata. J Nat Prod. 1984;47:459-464.

Feldmann M, Maini SR. Role of cytokines in rheumatoid arthritis: an education in pathophysiology and therapeutics. 
Immunol Rev. 2008;223:7-19.

Ferrero-Miliani L, Nielsen OH, Andersen PS, Girardin SE. Chronic inflammation: importance of NOD2 and NALP3 in interleukin-1beta generation. Clin Exp Immunol. 2007;147:227-235.

Grainger AJ, Rowbotham EL. Rheumatoid arthritis. Semin Musculoskelet Radiol. 2013;17:69-73.

Guinaudenu H, Leboeuf M, Cave A. Aporphine alkaloids. II. J Nat Prod. 1979;42:325-343.

Marok R, Winyard PG, Coumbe A, Kus ML, Gaffney K, Blades S, Mapp PI, Morris CJ, Blake DR, Kaltschmidt C, Baeuerle PA. Activation of the transcription factor nuclear factor-kappaB in human inflamed synovial tissue. Arthritis Rheum. 1996;39:583-591.

Milián L, Estellés R, Abarca B, Ballesteros R, Sanz MJ, Blázquez MA. Reactive oxygen species (ROS) generation inhibited by aporphine and phenanthrene alkaloids semisynthesized from natural boldine. Chem Pharm Bull. 2004;52:696-699.

Li Q, Chou G, Dou C, Wang Z, Huang F. Studies on the analgesic and anti-inflammatory action of Radix Linderae extract. Zhong Yao Cai. 1997;20:629-631.

Luo Y, Liu M, Dai Y, Yao X, Xia Y, Chou G, \& Wang Z. Norisoboldine inhibits the production of pro-inflammatory cytokines in lipopolysaccharide-stimulated RAW 264.7 cells by down-regulating the activation of MAPKs but not NF- $\mathrm{kB}$. Inflammation. 2010;33:389-397.

Luo Y, Liu M, Xia Y, Dai Y, Chou G, Wang Z. Therapeutic effect of norisoboldine, an alkaloid isolated from Radix Linderae, on collagen-induced arthritis in mice. Phytomedicine. 2010;17:726-731.

Luo Y, Liu M, Yao X, Xia Y, Dai Y, Chou G, \& Wang Z. Total alkaloids from Radix Linderae prevent the production of inflammatory mediators in lipopolysaccharide-stimulated RAW 264.7 cells by suppressing NF- $\mathrm{KB}$ and MAPKs activation. Cytokine. 2009;46:104-110.
Mix KS, Mengshol JA, Benbow U, Vincenti MP, Sporn MB, Brinckerhoff CE. A synthetic triterpenoid selectively inhibits the induction of matrix metalloproteinases 1 and 13 by inflammatory cytokines. Arthritis Rheum. 2001;44:1096-1104.

Rachmatiah T, Mukhtar MR, Nafiah MA, Hanafi M, Kosela S, Morita H, Litaudon M, Awang K, Omar H, Hadi AH. (+)-N-(2hydroxypropyl) lindcarpine: a new cytotoxic aporphine isolated from Actinodaphne pruinosa Nees. Molecules. 2009;14:28502856.

Scott DL, Wolfe F, Huizinga TW. Rheumatoid arthritis. Lancet. 2010;376:1094-1108.

Tak PP, Bresnihan B. The pathogenesis and prevention of joint damage in rheumatoid arthritis: advances from synovial biopsy and tissue analysis. Arthritis Rheum. 2000;43:2619-2633.

Xiao Y, Li Z Y, Li L. Chemical constituents (II) from Litsea euosma W. W. Smith. Yunnan Chemical Technology. 2006;33:22-23.

Xiao Y, Yang XD, Zhou HJ, Zhao JF, Yang JH, Li L. Isoquinoline alkaloids from Litsea euosma. Journal of Yunnan University. 2004;26:192-193. http://www.cqvip.com/qk/92787x /2004b07/10058518.html

Winer J, Jung CK, Shackel I, Williams PM. Development and validation of real-time quantitative reverse transcriptasepolymerase chain reaction for monitoring gene expression in cardiac myocytes in vitro. Anal Biochem. 1999;270:41-49.

Yu R, Ye Q, Chen B, Zhang GL. Chemical study on Mitrephora Natural Product Research and Development. 2003;15:212-215.

Zhu CL, Yang PM. Isolation and structure identification of chemical constituents from the root of Litsea cubeba. Chinese Journal of Pharmaceuticals. 2007;38:558-560. http://www.cqvip.com/qk/92282x/200708/25126172.html 


\section{Supplementary data}

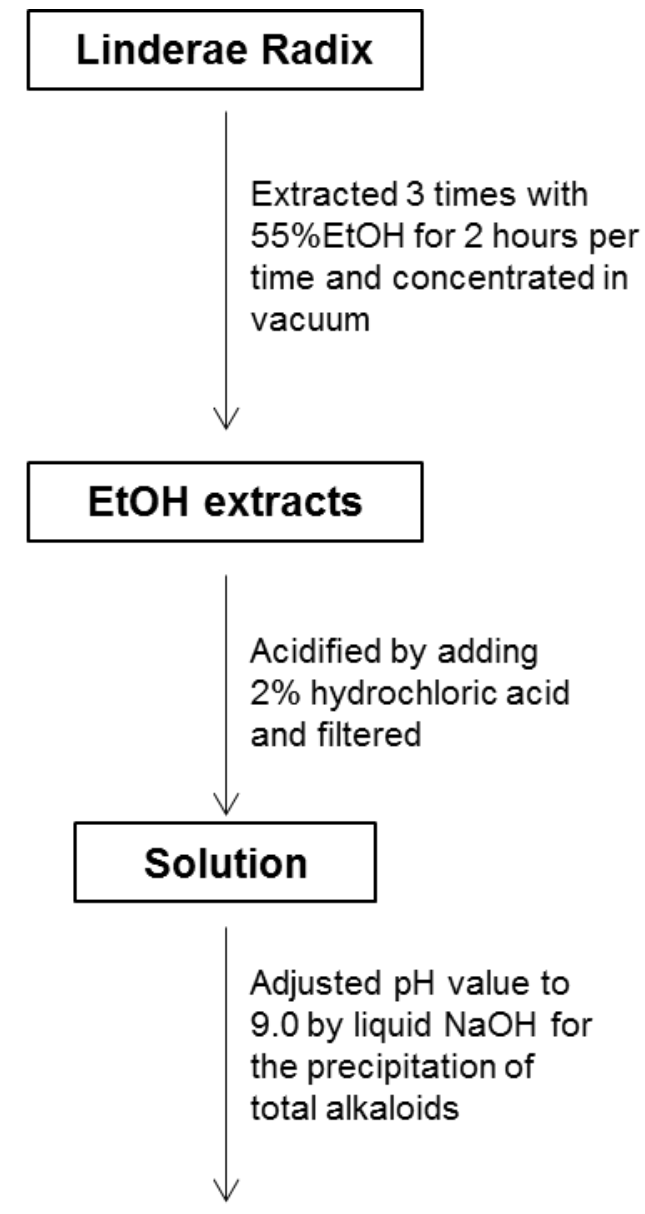

\section{Total alkaloids}

Fig. 1S. The extraction method of total alkaloids. Linderae Radix was powdered first, and then weighed for around eighty kilograms to process with reference to the flowchart describ ed above. 


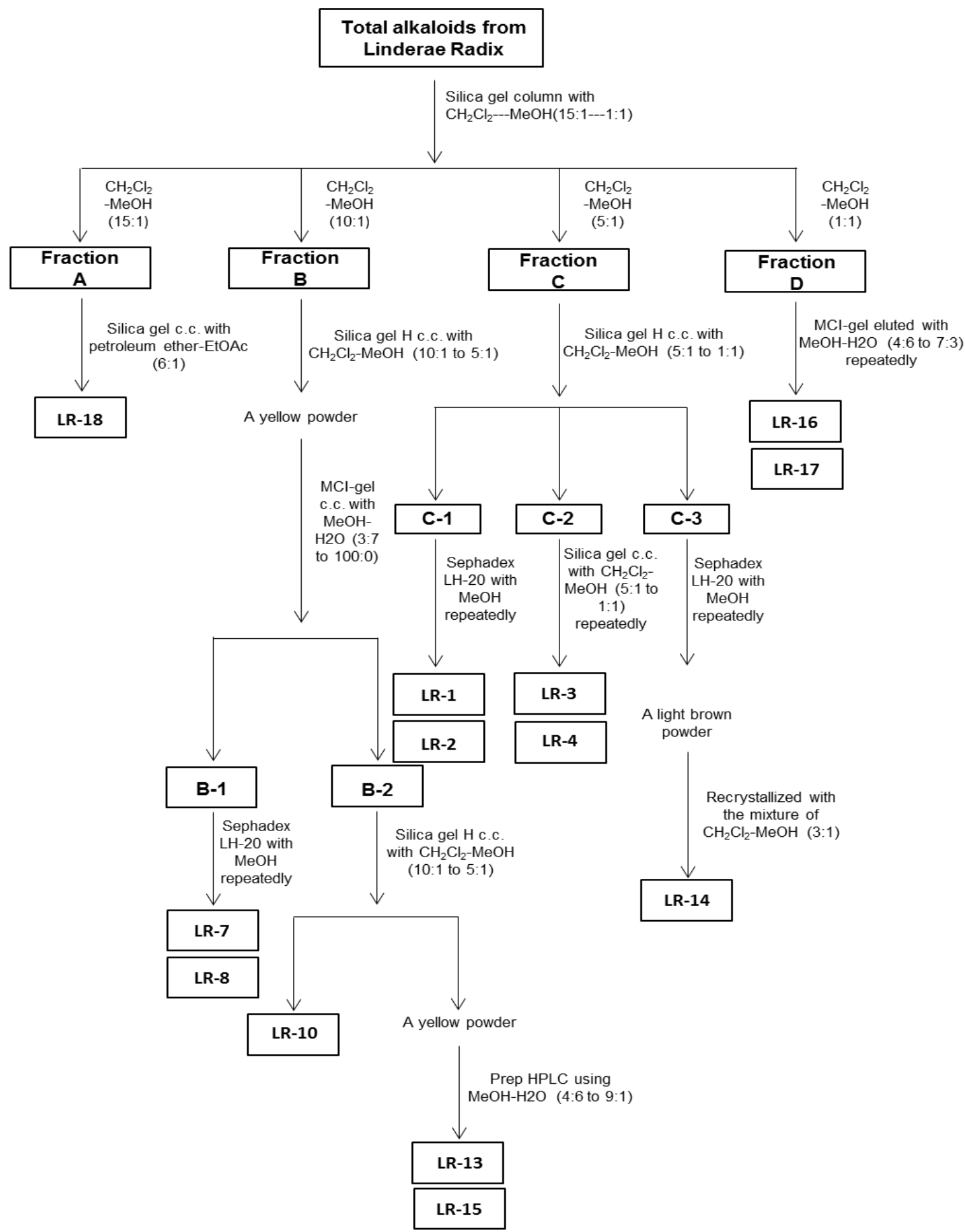

Fig. 2S. The isolation of individual compounds from total alkaloids. About 200 grams of total alkaloids extracted from Linderae Radix were loaded onto the silica gel column, and its fractions were then separated mainly by silica gel high-performance, sephadex LH-20 and MCI-gel column respectively to obtain 13 individual compounds. 


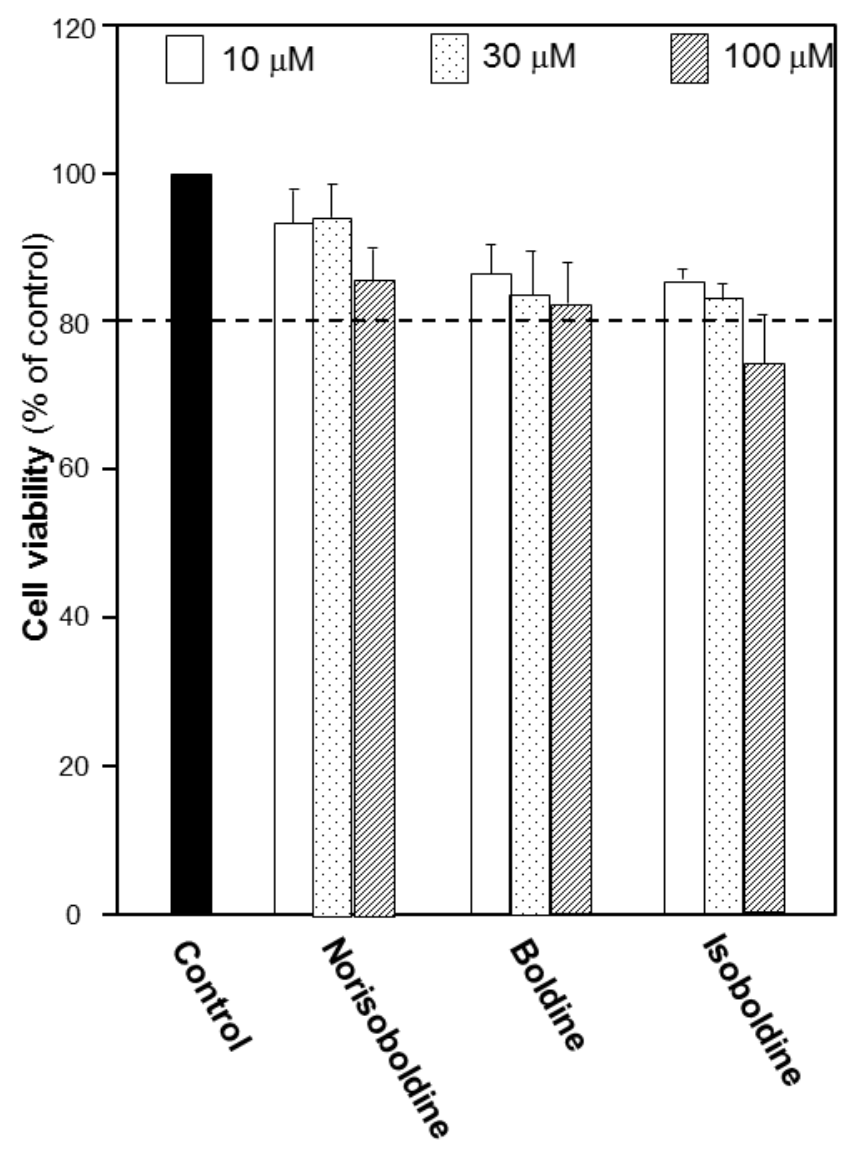

Fig. 3S. Effects of isoquinoline alkaloids on the growth of macrophage RAW 264.7 cells. Several concentrations of isoquinoline alkaloids $(10,30,100 \mu \mathrm{M})$ were applied onto cultured RAW 264.7 cells for 24 hours. The cell viability was then carried out by using colorimetric MTT assay. Values were expressed in Mean $\pm \mathrm{SD}, n=3$. 
A

\section{Appendix}

WV-1\#10 RT: 0.39 AV: 1 SB: $40.02-0.07,0.35-0.51$ NL: $1.06 E 8$

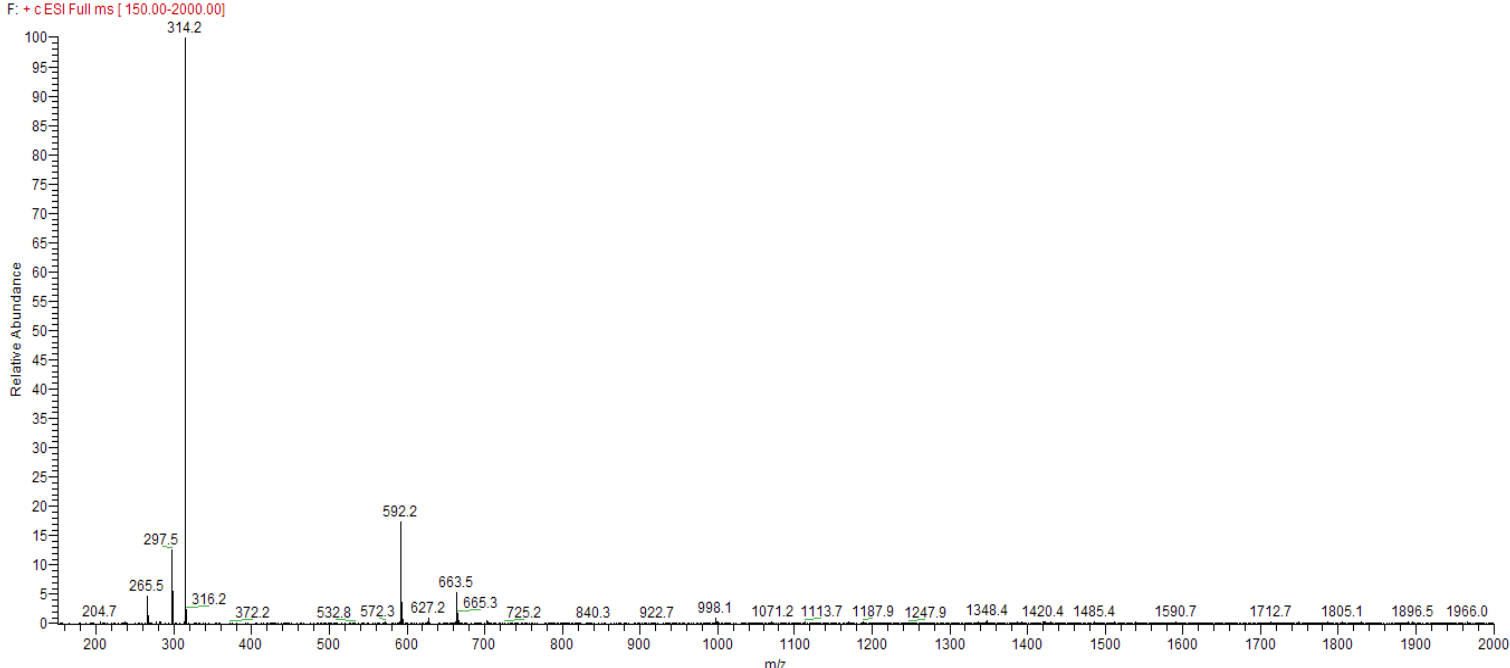

B

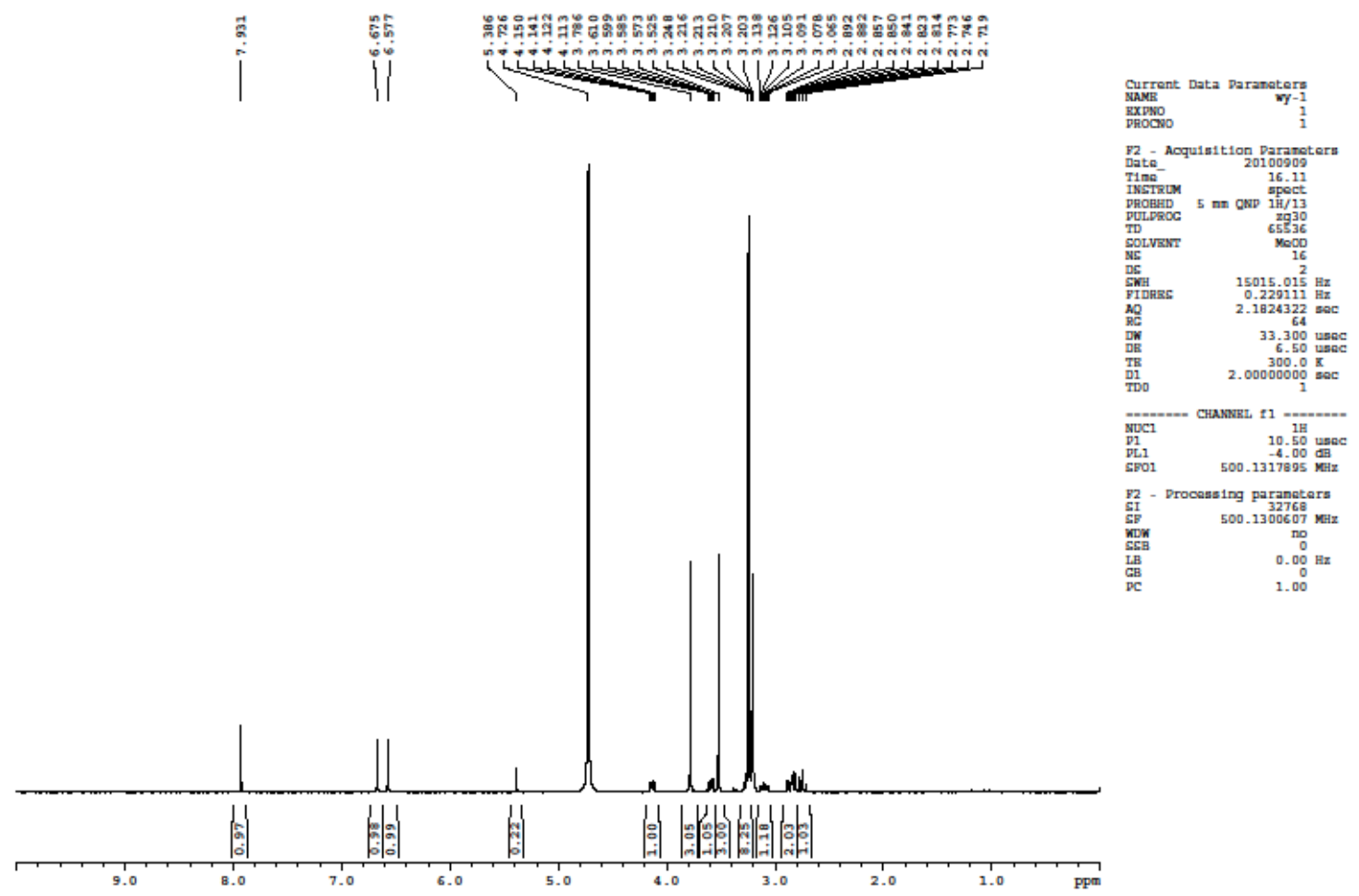




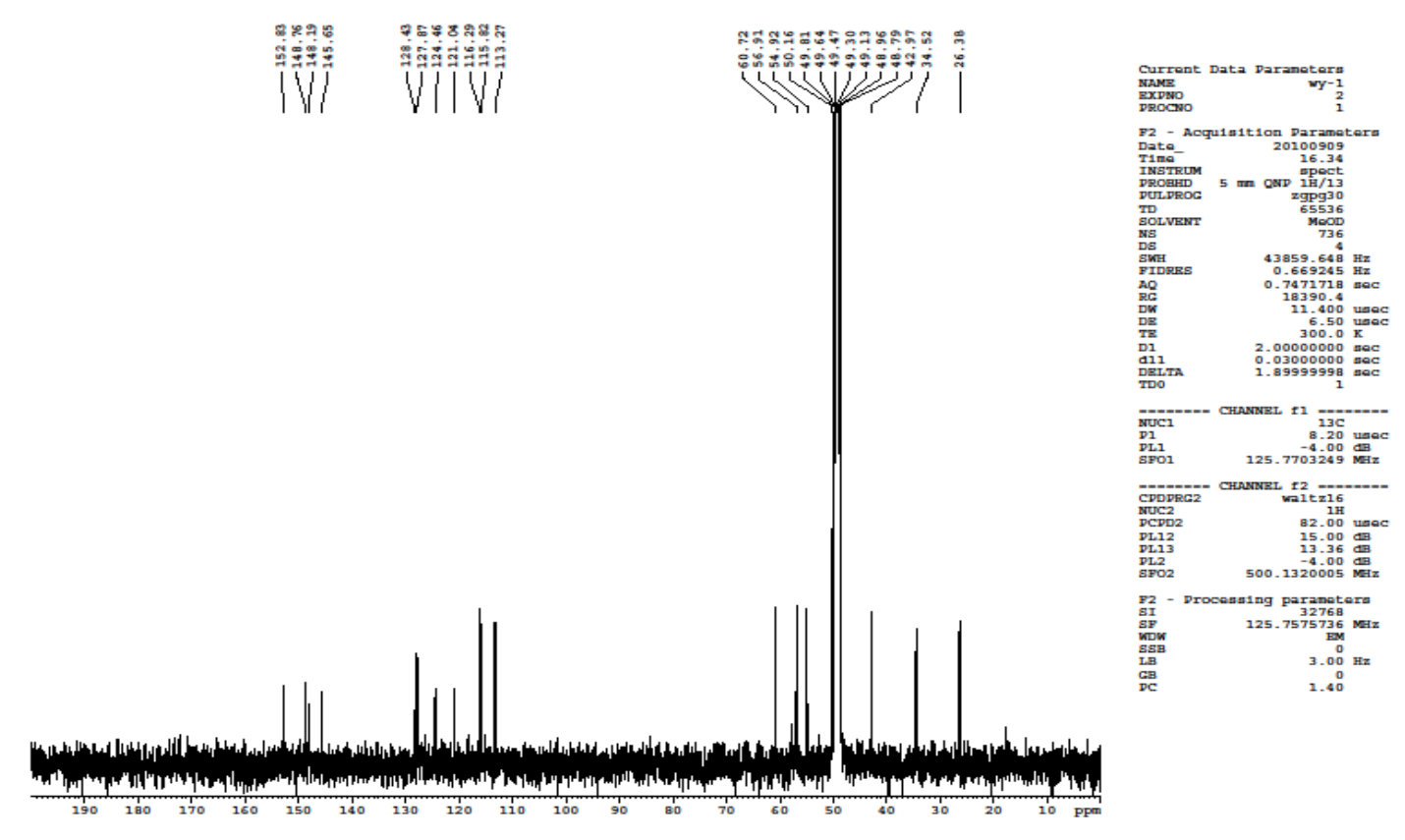

1. ESI-MS, ${ }^{1} \mathrm{H}-\mathrm{NMR}$ and ${ }^{13} \mathrm{C}$-NMR spectra of norisoboldine. (A) ESI-MS $[\mathrm{M}+\mathrm{H}]^{+}$of norisoboldine, (B) The ${ }^{1} \mathrm{H}-\mathrm{NMR}$ of norisoboldine, (C) The ${ }^{13} \mathrm{C}-\mathrm{NMR}$ of norisoboldine. Norisoboldine: A colorless bulk crystalline $(\mathrm{MeOH})$, ESI-MS m/x : $314.2[\mathrm{M}+\mathrm{H}]^{+}{ }^{1} \mathrm{H}-\mathrm{NMR}$ $\left(\mathrm{CD}_{3} \mathrm{OD}, 500 \mathrm{MHz}\right) \delta_{\mathrm{H}}: 7.91(1 \mathrm{H}, \mathrm{s}, \mathrm{H}-11), 6.67(1 \mathrm{H}, \mathrm{s}, \mathrm{H}-8), 6.57(1 \mathrm{H}, \mathrm{s}, \mathrm{H}-3), 3.77(3 \mathrm{H}, \mathrm{s}, 2-$ $\left.\mathrm{OCH}_{3}\right), 352\left(3 \mathrm{H}, \mathrm{s}, 10-\mathrm{OCH}_{3}\right), 4.12(1 \mathrm{H}, \mathrm{dd}, \mathrm{J}=4.5 \mathrm{~Hz}, 14.0 \mathrm{~Hz}, \mathrm{H}-6 \mathrm{a}), 3.59(1 \mathrm{H}, \mathrm{m}, \mathrm{H}-5 \mathrm{a})$, $3.24(1 \mathrm{H}, \mathrm{m}, \mathrm{H}-5 \mathrm{~b}), 3.10(1 \mathrm{H}, \mathrm{m}, \mathrm{H}-4 \mathrm{a}), 2.86(1 \mathrm{H}, \mathrm{dd}, \mathrm{J}=4.0,16.5 \mathrm{~Hz}, \mathrm{H}-4 \mathrm{~b}), 2.83(1 \mathrm{H}, \mathrm{dd}, \mathrm{J}=4.5$, $13.0 \mathrm{~Hz}, \mathrm{H}-7 \mathrm{a}), 2.74(1 \mathrm{H}, \mathrm{t}, \mathrm{J}=13.0 \mathrm{~Hz}, \mathrm{H}-7 \mathrm{~b}) .{ }^{13} \mathrm{C}-\mathrm{NMR}\left(\mathrm{CD}_{3} \mathrm{OD}, 125 \mathrm{MHz}\right) \delta_{\mathrm{C}}: 152.8(\mathrm{C}-1)$, 145.6 (C-2), 115.8 (C-3), 121.0 (C-3a), 26.4 (C-4), 42.9 (C-5), 54.9 (C-6a), 34.5 (C-7), 126.4 (C-7a), 116.3 (C-8), 148.1 (C-9), 148.7 (C-10), 113.3 (C-11), 124.5 (C-11a), 128.4 (C-11b), 127.9 (C-11c), 56.9 (C2-OMe), 60.7 (C10-OMe).

A

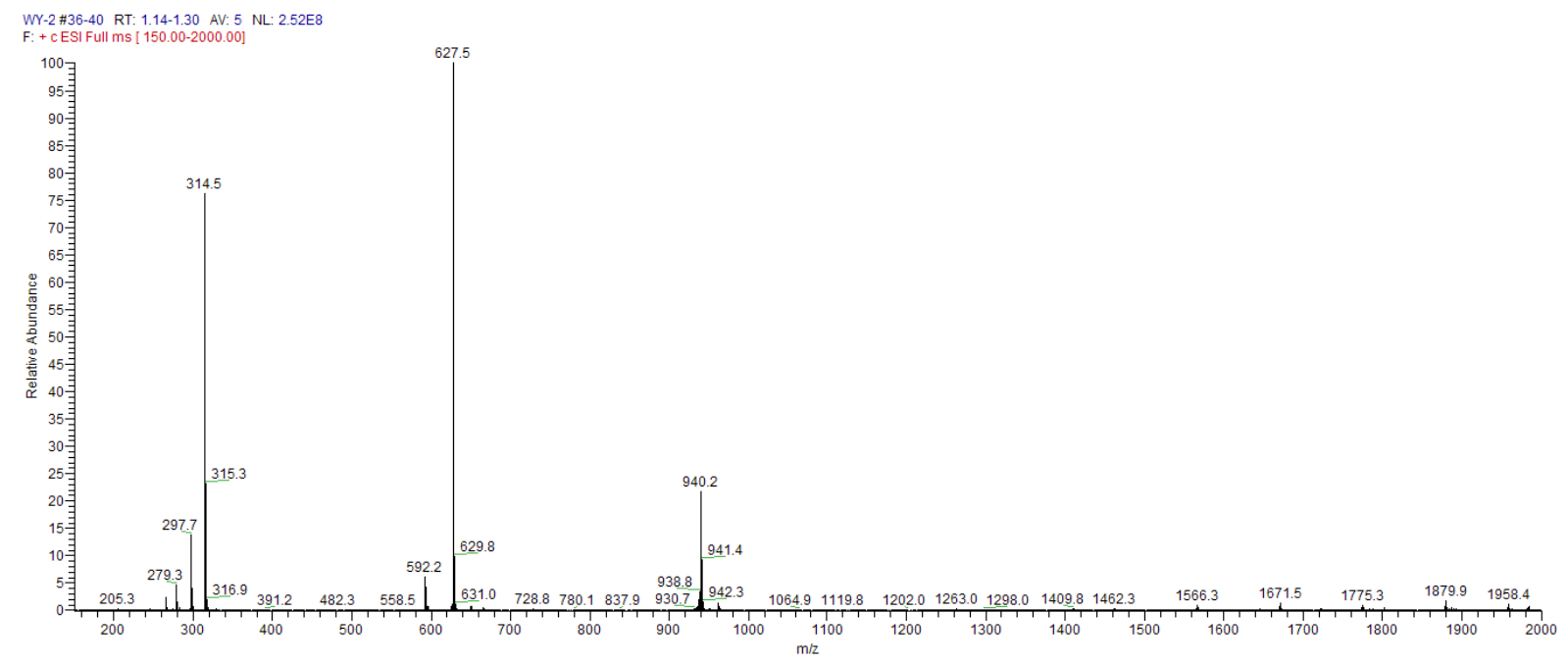




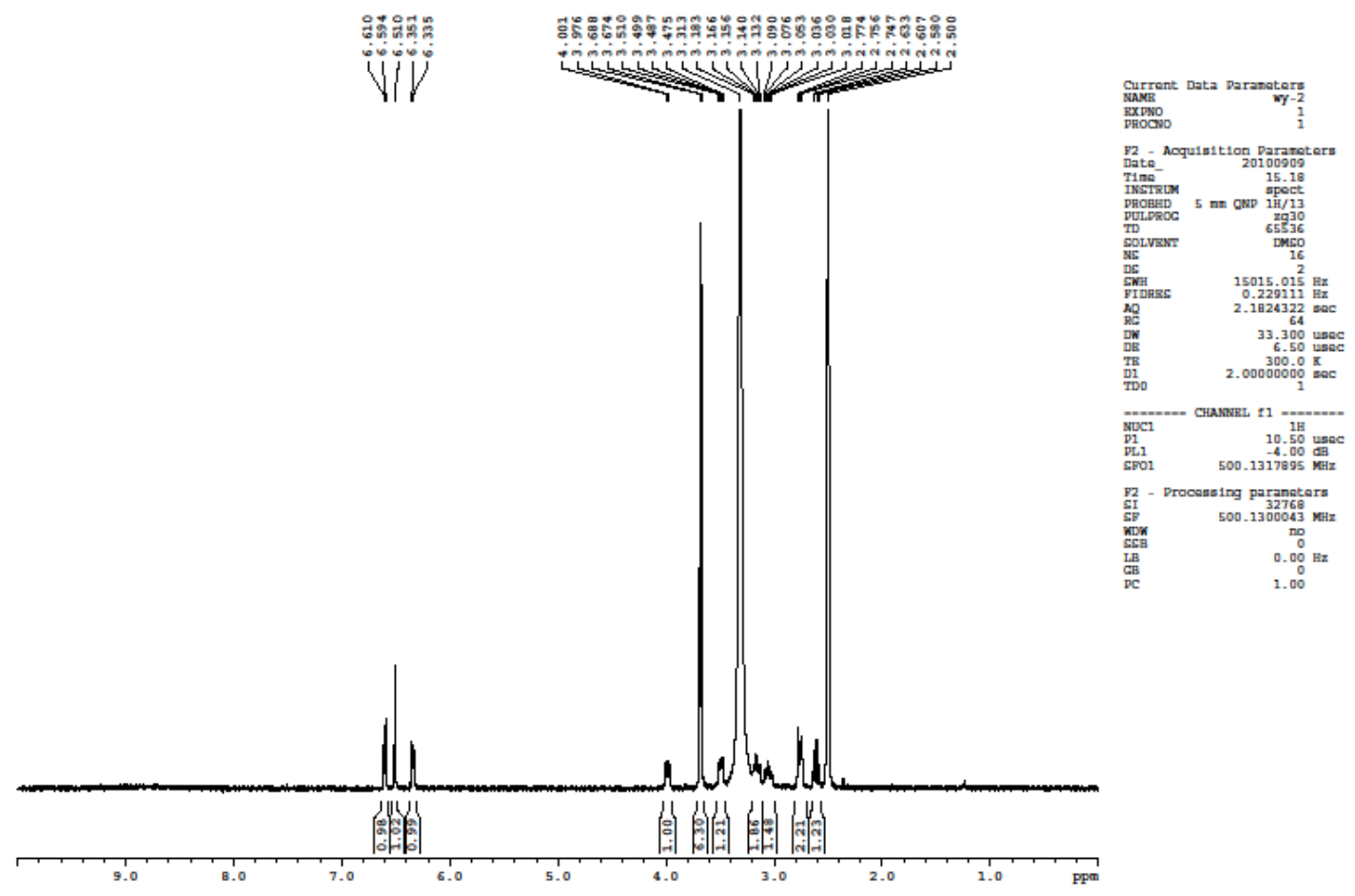

C

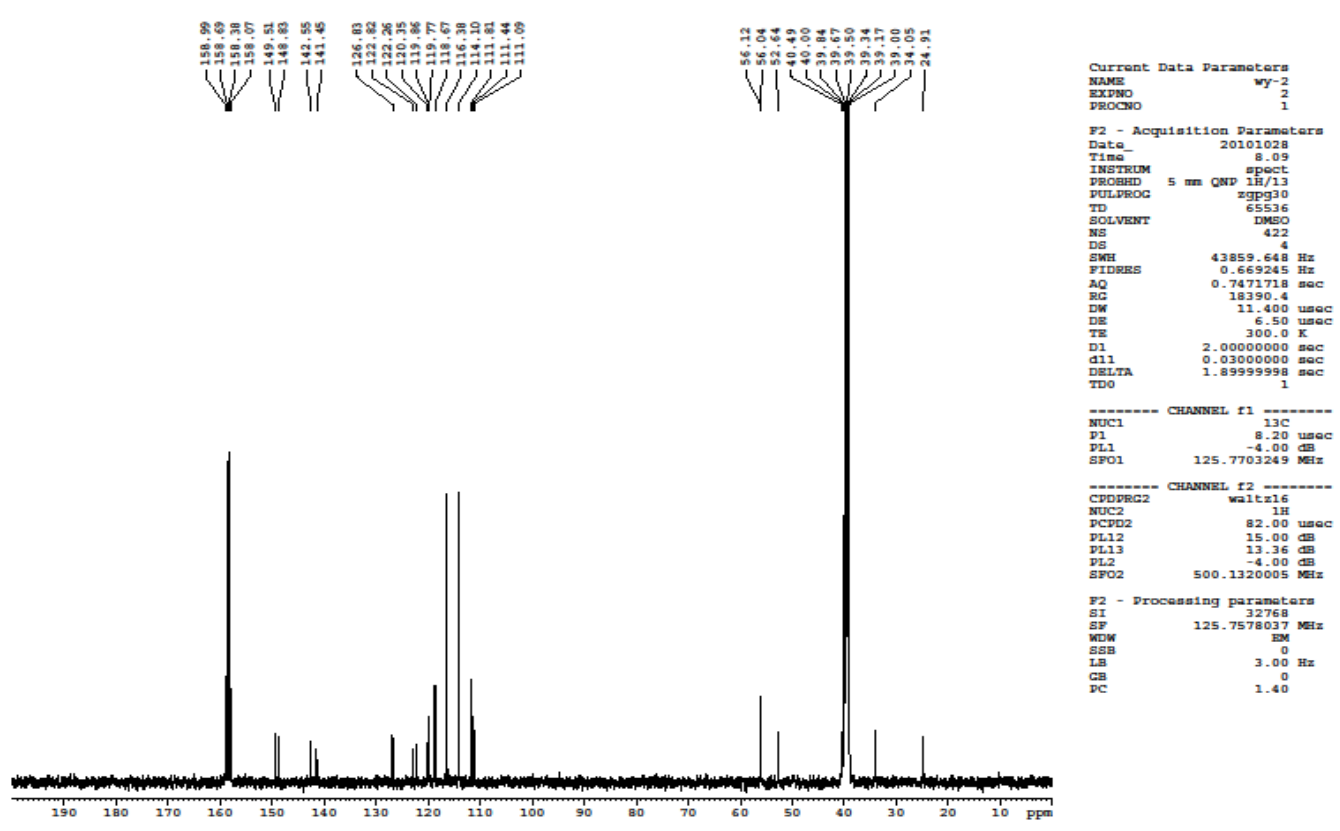

2. ESI-MS, ${ }^{1} \mathrm{H}-\mathrm{NMR}$ and ${ }^{13} \mathrm{C}$-NMR spectra of lindcarpine. (A) ESI-MS $[\mathrm{M}+\mathrm{H}]^{+}$of lindcarpine, (B) The ${ }^{1} \mathrm{H}-\mathrm{NMR}$ of lindcarpine, (C) The ${ }^{13} \mathrm{C}-\mathrm{NMR}$ of lindcarpine. Lindcarpine: Light brown powder $(\mathrm{MeOH})$, ESI-MS m/z : $314.5[\mathrm{M}+\mathrm{H}]^{+}$. ${ }^{1} \mathrm{H}-\mathrm{NMR}\left(\mathrm{DMSO}-\mathrm{d}_{6}, 500 \mathrm{MHz}\right) \delta_{\mathrm{H}}: 6.60(1 \mathrm{H}, \mathrm{d}, \mathrm{J}$ $=8.00 \mathrm{~Hz}, \mathrm{H}-9), 6.34(1 \mathrm{H}, \mathrm{d}, \mathrm{J}=8.00 \mathrm{~Hz}, \mathrm{H}-8), 6.51(1 \mathrm{H}, \mathrm{s}, \mathrm{H}-3), 3.69\left(3 \mathrm{H}, \mathrm{s}, 10-\mathrm{OCH}_{3}\right), 3.67(3 \mathrm{H}$, s, $\left.1-\mathrm{OCH}_{3}\right), 3.49(1 \mathrm{H}, \mathrm{dd}, \mathrm{J}=5.50 \mathrm{~Hz}, 11.5 \mathrm{~Hz}, \mathrm{H}-6 \mathrm{a}), 3.18 \sim 2.61(6 \mathrm{H}, \mathrm{m}, \mathrm{H}-4, \mathrm{H}-5, \mathrm{H}-7) .{ }^{13} \mathrm{C}-$ 
NMR (DMSO-d 6 , 125 MHz) $\delta_{\mathrm{C}}: 141.5$ (C-1), 148.8 (C-2), 114.1 (C-3), 122.8 (C-3a), 24.9 (C-4), 40.5 (C-5), 56.0 (C-6a), 34.1 (C-7), 122.3 (C-7a), 119.8 (C-8), 111.4 (C-9), 149.5 (C-10), 142.6 (C11), 119.9 (C-11a), 120.4 (C-11b), 126.8 (C-11c), 56.1 (C1-OMe), 52.6 (C10-OMe).

A

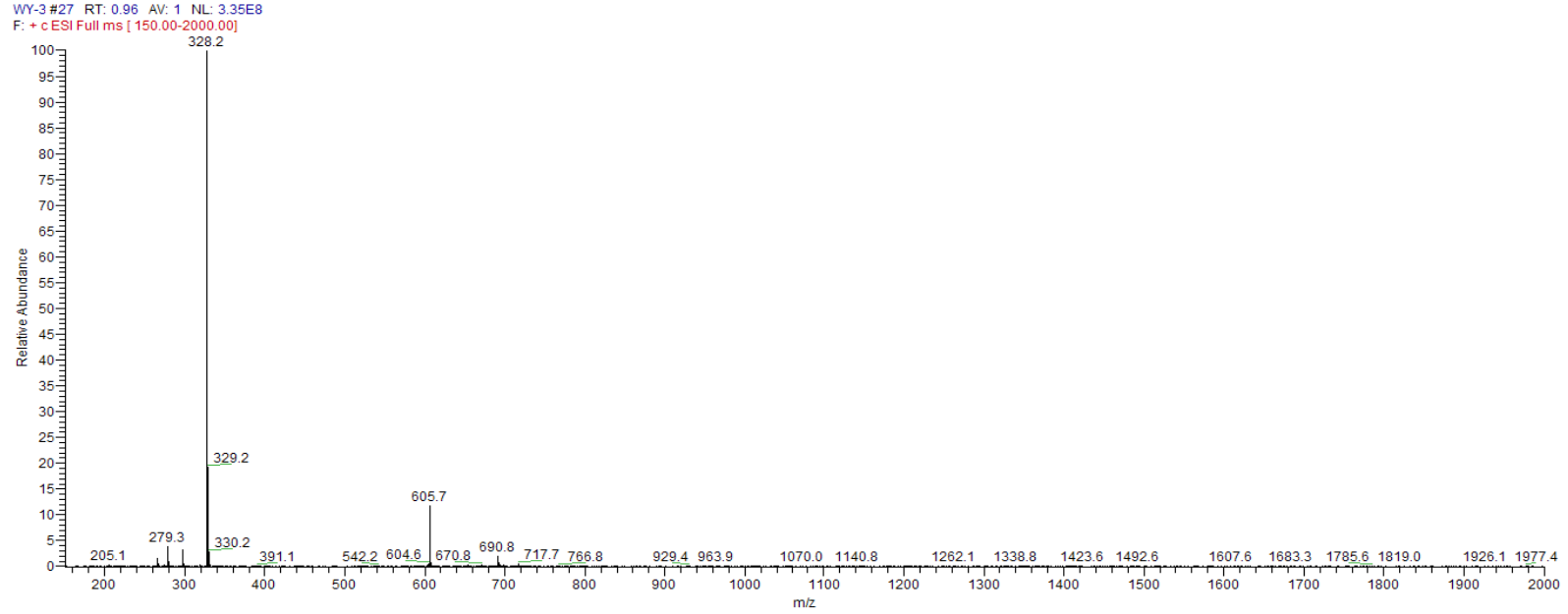

B

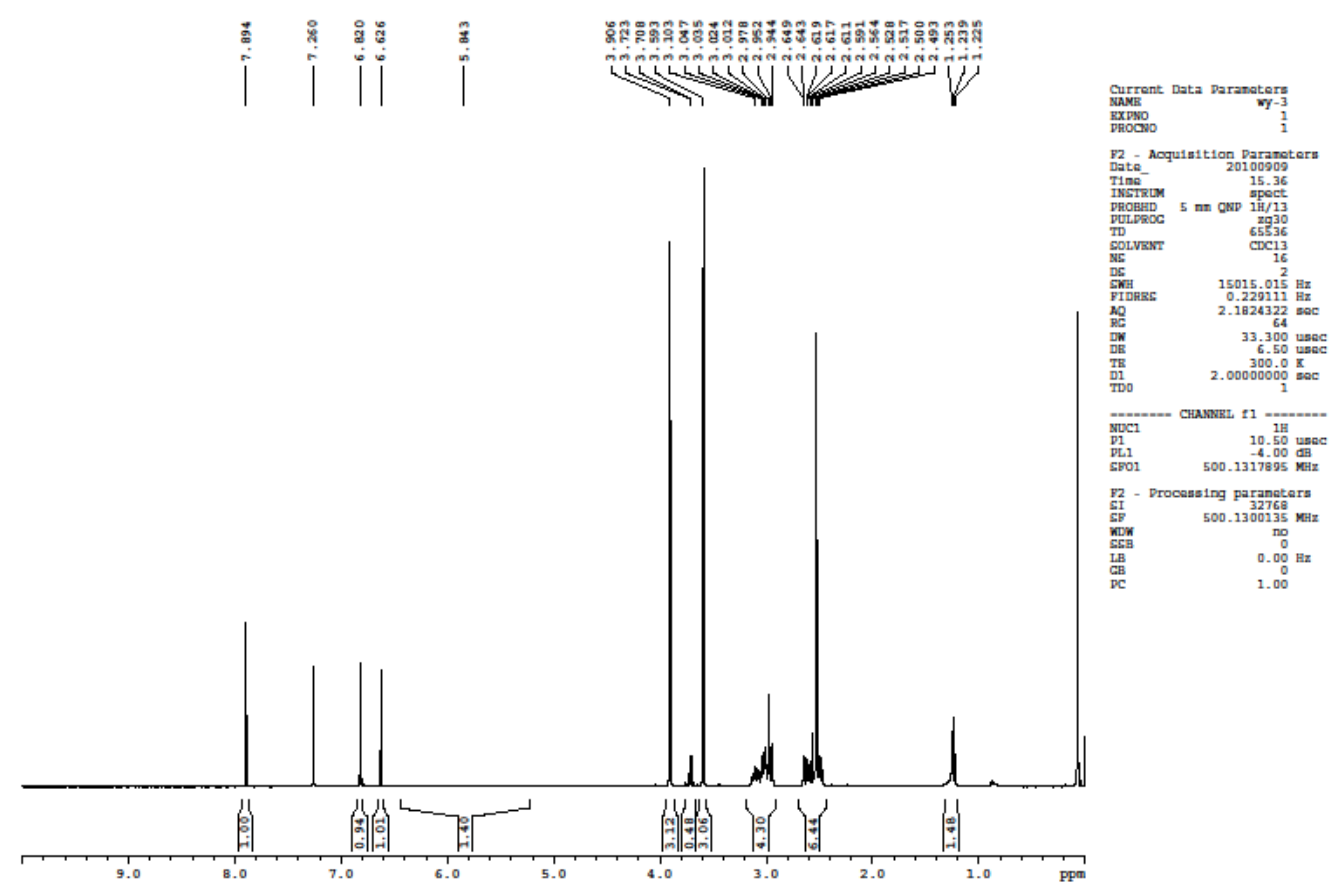


C

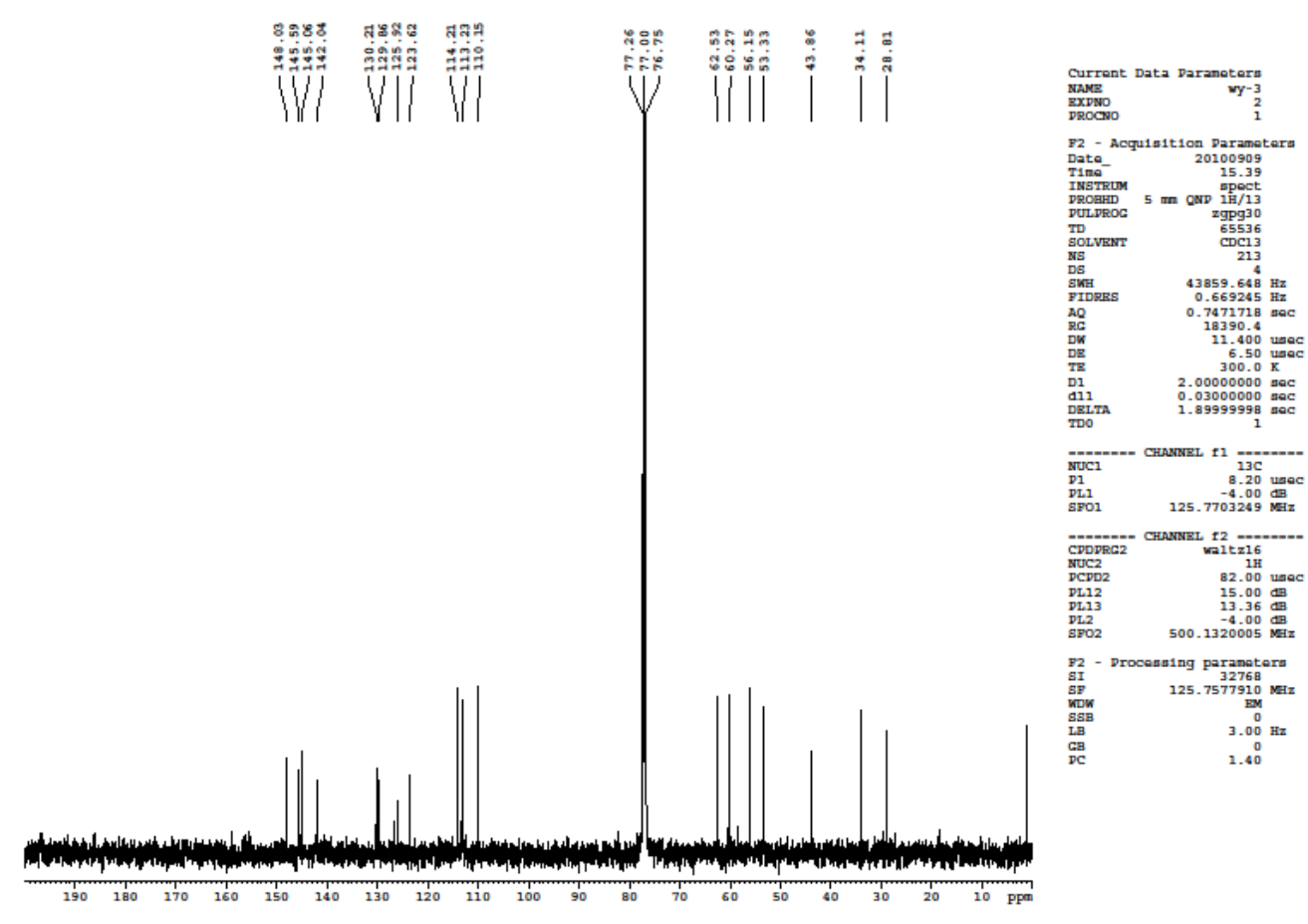

3. ESI-MS, ${ }^{1} \mathrm{H}-\mathrm{NMR}$ and ${ }^{13} \mathrm{C}$-NMR spectra of boldine. (A) ESI-MS $[\mathrm{M}+\mathrm{H}]^{+}$of boldine, (B) The ${ }^{1} \mathrm{H}-\mathrm{NMR}$ of boldine, (C) The ${ }^{13} \mathrm{C}-\mathrm{NMR}$ of boldine. Boldine: Light brown powder (MeOH), ESI-MS m/z: $328.2[\mathrm{M}+\mathrm{H}]^{+} .{ }^{1} \mathrm{H}-\mathrm{NMR}\left(\mathrm{CDCl}_{3}, 500 \mathrm{MHz}\right) \delta_{\mathrm{H}}: 7.89(1 \mathrm{H}, \mathrm{s}, \mathrm{H}-11), 6.82(1$ $\mathrm{H}, \mathrm{s}, \mathrm{H}-8), 6.63(1 \mathrm{H}, \mathrm{s}, \mathrm{H}-3), 3.91\left(3 \mathrm{H}, \mathrm{s}, 10-\mathrm{OCH}_{3}\right), 3.59\left(3 \mathrm{H}, \mathrm{s}, 2-\mathrm{OCH}_{3}\right), 2.53(3 \mathrm{H}, \mathrm{s}$, - $\left.\mathrm{NCH}_{3}\right), 3.10 \sim 2.94(4 \mathrm{H}, \mathrm{m}, \mathrm{H}-6 \mathrm{a}, \mathrm{H}-5, \mathrm{H}-7-\mathrm{a}), 2.72 \sim 2.41(3 \mathrm{H}, \mathrm{m}, \mathrm{H}-7-\mathrm{b}, \mathrm{H}-4) .{ }^{13} \mathrm{C}-\mathrm{NM}$ $\mathrm{R}\left(\mathrm{CDCl}_{3}, 125 \mathrm{MHz}\right) \delta_{\mathrm{C}}: 142.0(\mathrm{C}-1), 148.0(\mathrm{C}-2), 113.2(\mathrm{C}-3), 129.9$ (C-3a), 28.8 (C-4), 53.3 (C-5), 62.5 (C-6a), 34.1 (C-7), 130.2 (C-7a), 114.2 (C-8), 145.1 (C-9), 145.6 (C-10), 1 10.2 (C-11), 126.8 (C-11a), 125.9 (C-11b), 123.6 (C-11c), 60.3 (C1-OMe), 56.2 (C10-OMe), $43.9\left(\mathrm{~N}-\mathrm{CH}_{3}\right)$.

A

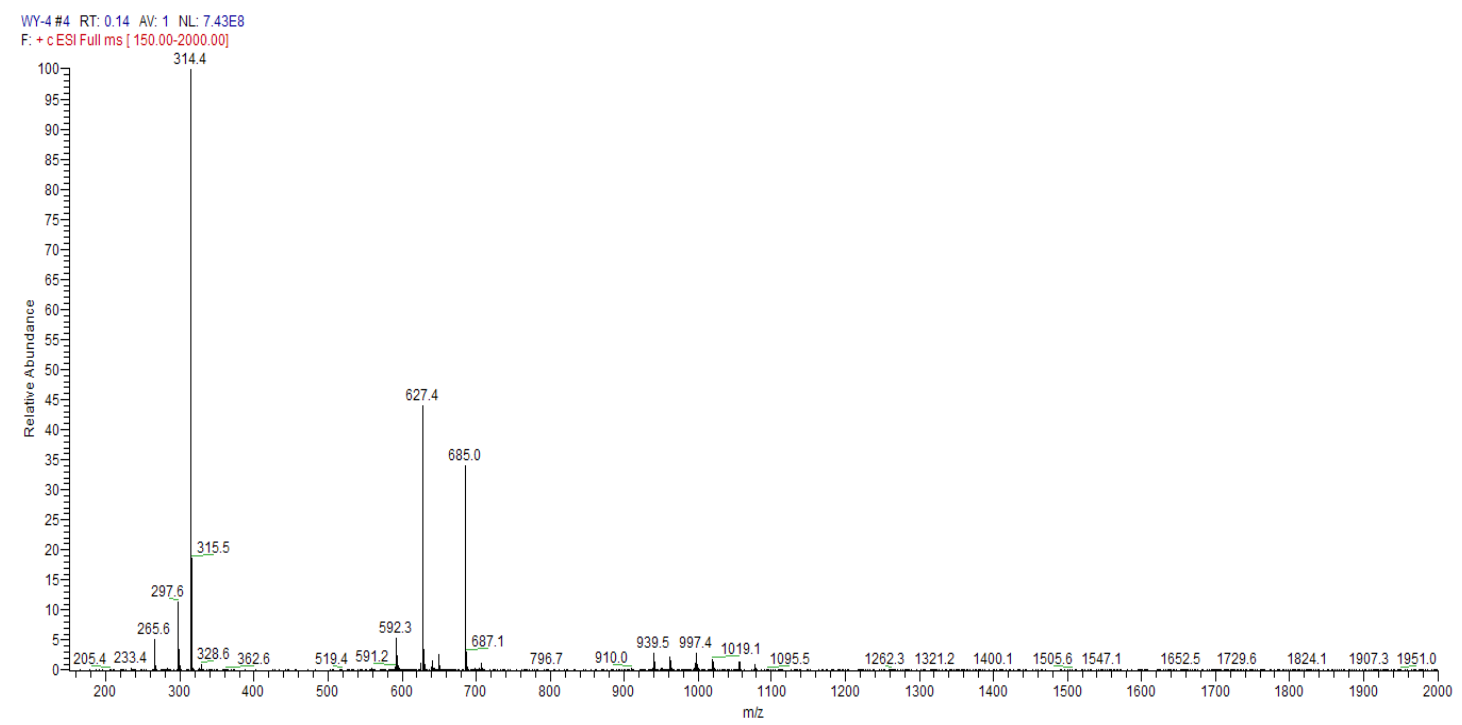




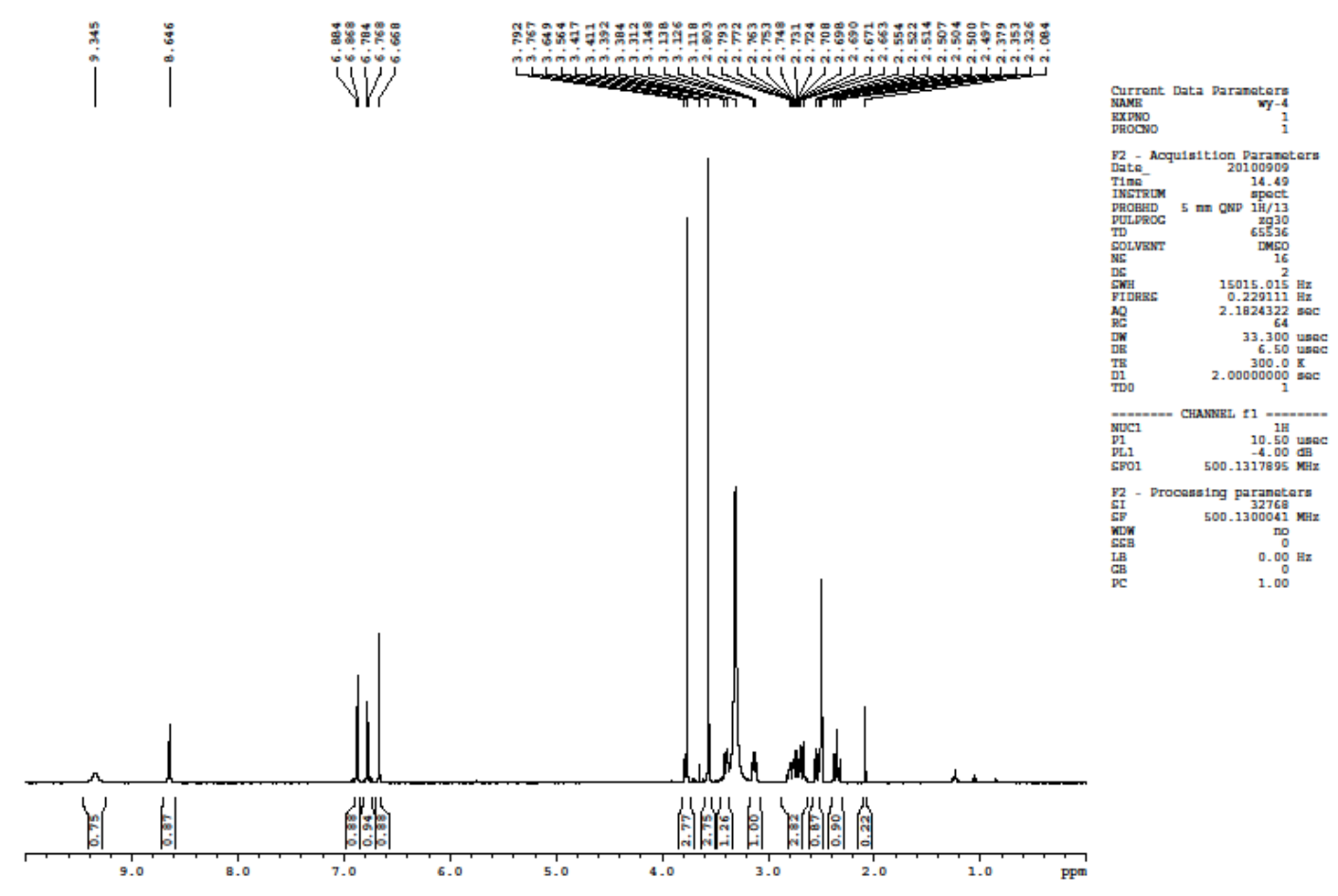

C

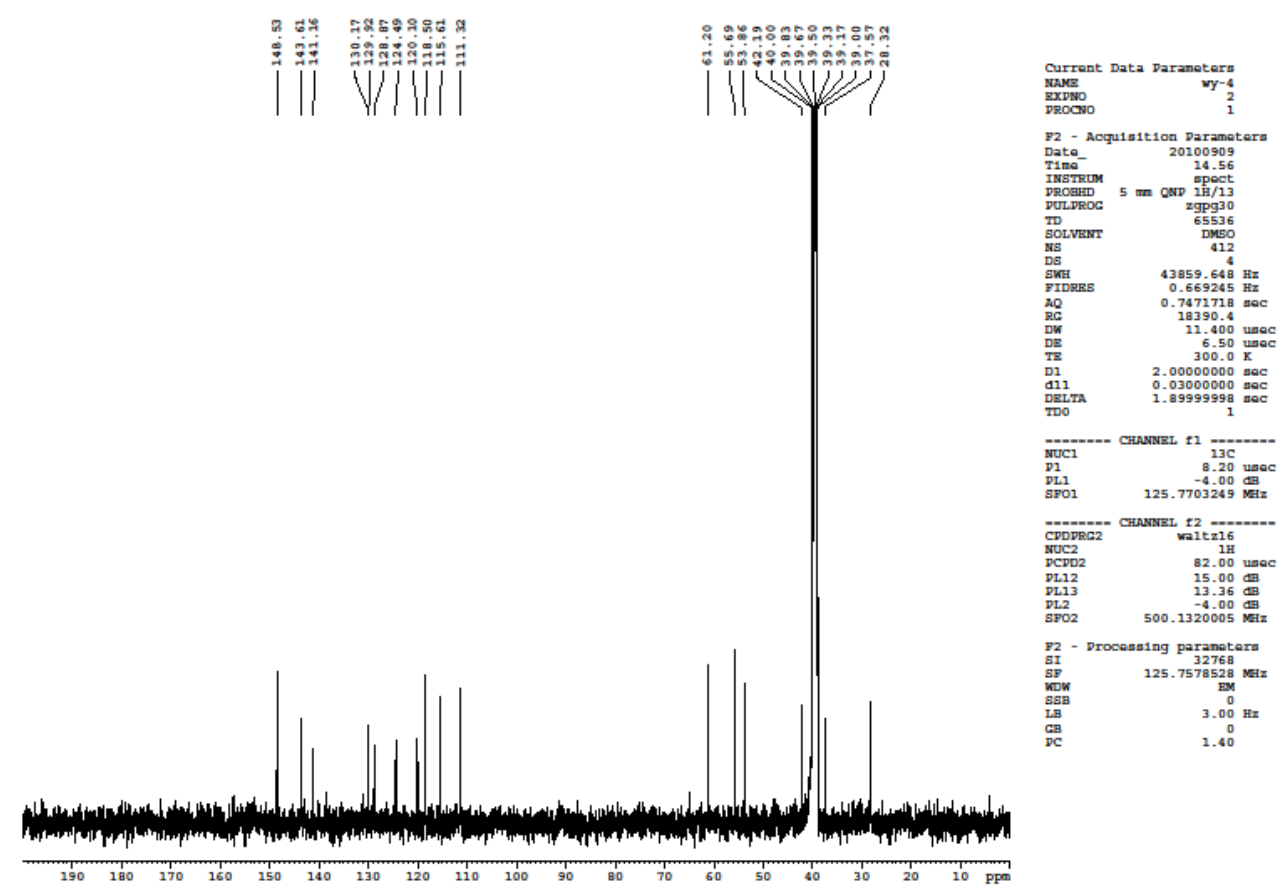

4. ESI-MS, ${ }^{1} \mathrm{H}-\mathrm{NMR}$ and ${ }^{13} \mathrm{C}$-NMR spectra of linderaline. (A) ESI-MS $[\mathrm{M}+\mathrm{H}]^{+}$of 1 inderaline, (B) The ${ }^{1} \mathrm{H}-\mathrm{NMR}$ of linderaline, (C) The ${ }^{13} \mathrm{C}-\mathrm{NMR}$ of linderaline. Linderaline: Light 
brown amorphous powder $(\mathrm{MeOH})$, ESI-MS m/z : $314.4[\mathrm{M}+\mathrm{H}]^{+} .{ }^{1} \mathrm{H}-\mathrm{NMR}\left(\mathrm{DMSO}-\mathrm{d}_{6}, 500 \mathrm{MHz}\right)$ $\delta \mathrm{H}: 6.87(1 \mathrm{H}, \mathrm{d}, \mathrm{J}=8.00 \mathrm{~Hz}, \mathrm{H}-9), 6.77(1 \mathrm{H}, \mathrm{d}, \mathrm{J}=8.00 \mathrm{~Hz}, \mathrm{H}-8), 6.67(1 \mathrm{H}, \mathrm{s}, \mathrm{H}-3), 3.77(3 \mathrm{H}$, $\left.\mathrm{s}, 10-\mathrm{OCH}_{3}\right), 3.56\left(3 \mathrm{H}, \mathrm{s}, 11-\mathrm{OCH}_{3}\right), 3.40(1 \mathrm{H}, \mathrm{dd}, \mathrm{J}=4.00 \mathrm{~Hz}, 12.5 \mathrm{~Hz}, \mathrm{H}-6 \mathrm{a}), 3.13(1 \mathrm{H}, \mathrm{dd}, \mathrm{J}=$ $4.00 \mathrm{~Hz}, 11.0 \mathrm{~Hz}, \mathrm{H}-5 \mathrm{a}), 2.80 \sim 2.33(5 \mathrm{H}, \mathrm{m}, \mathrm{H}-4, \mathrm{H}-5-\mathrm{b}, \mathrm{H}-7) .{ }^{13} \mathrm{C}-\mathrm{NMR}$ (DMSO-d 6 , $125 \mathrm{MHz}$ ) $\delta_{\mathrm{C}}: 141.2(\mathrm{C}-1), 150.1$ (C-2), 115.6 (C-3), 130.2 (C-3a), 28.3 (C-4), 42.2 (C-5), 53.9 (C-6a), 37.6 (C-7), 129.9 (C-7a), 118.5 (C-8), 111.3 (C-9), 148.5 (C-10), 143.6 (C-11), 120.1 (C-11a), 124.5 (C11b), 128.9 (C-11c), 55.7 (C10-OMe), 61.2 (C11-OMe).

A

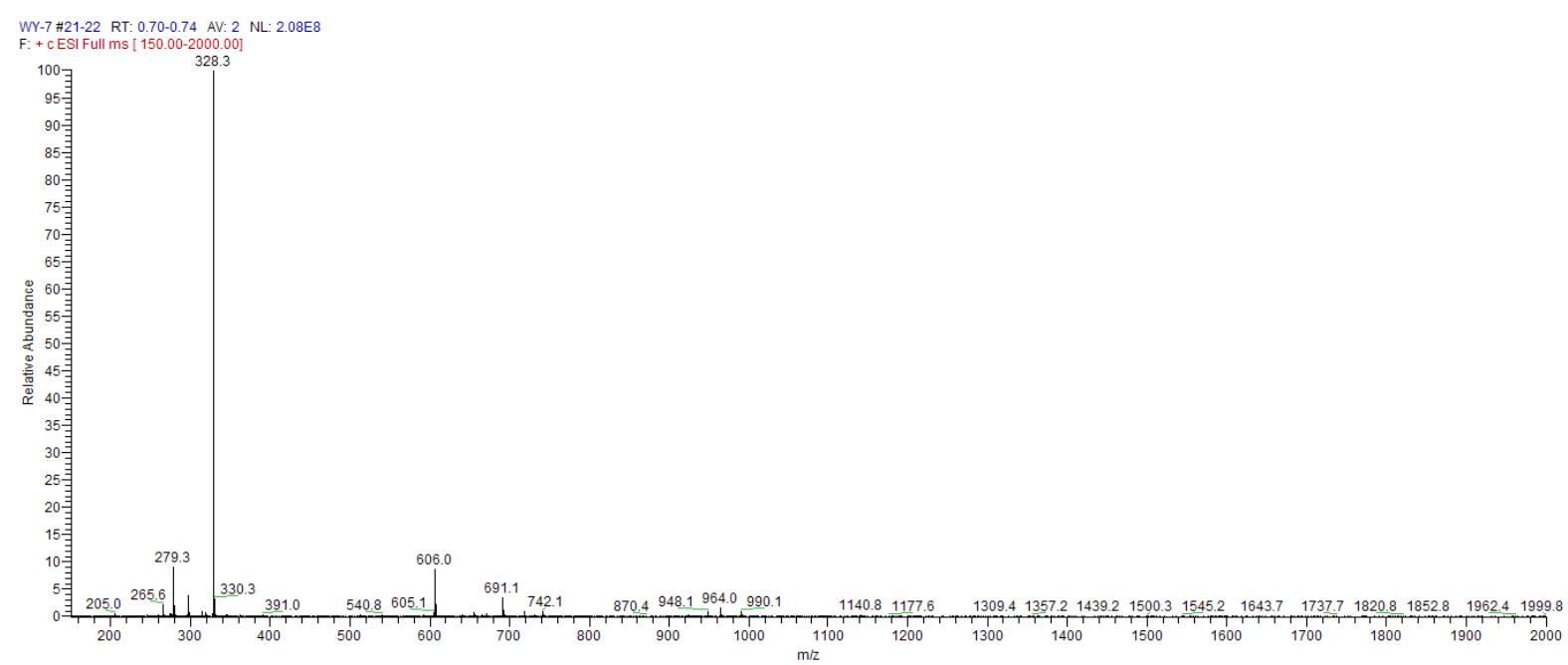

B

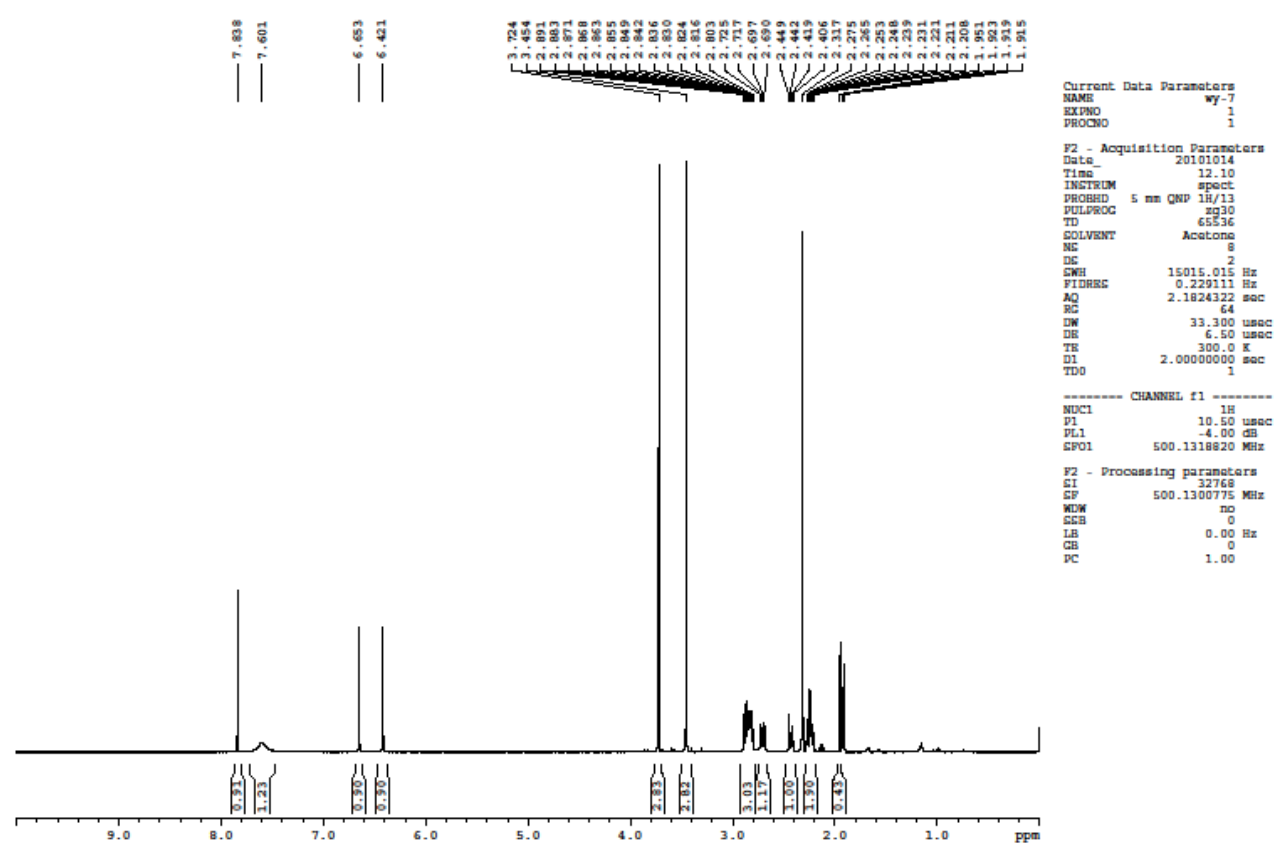




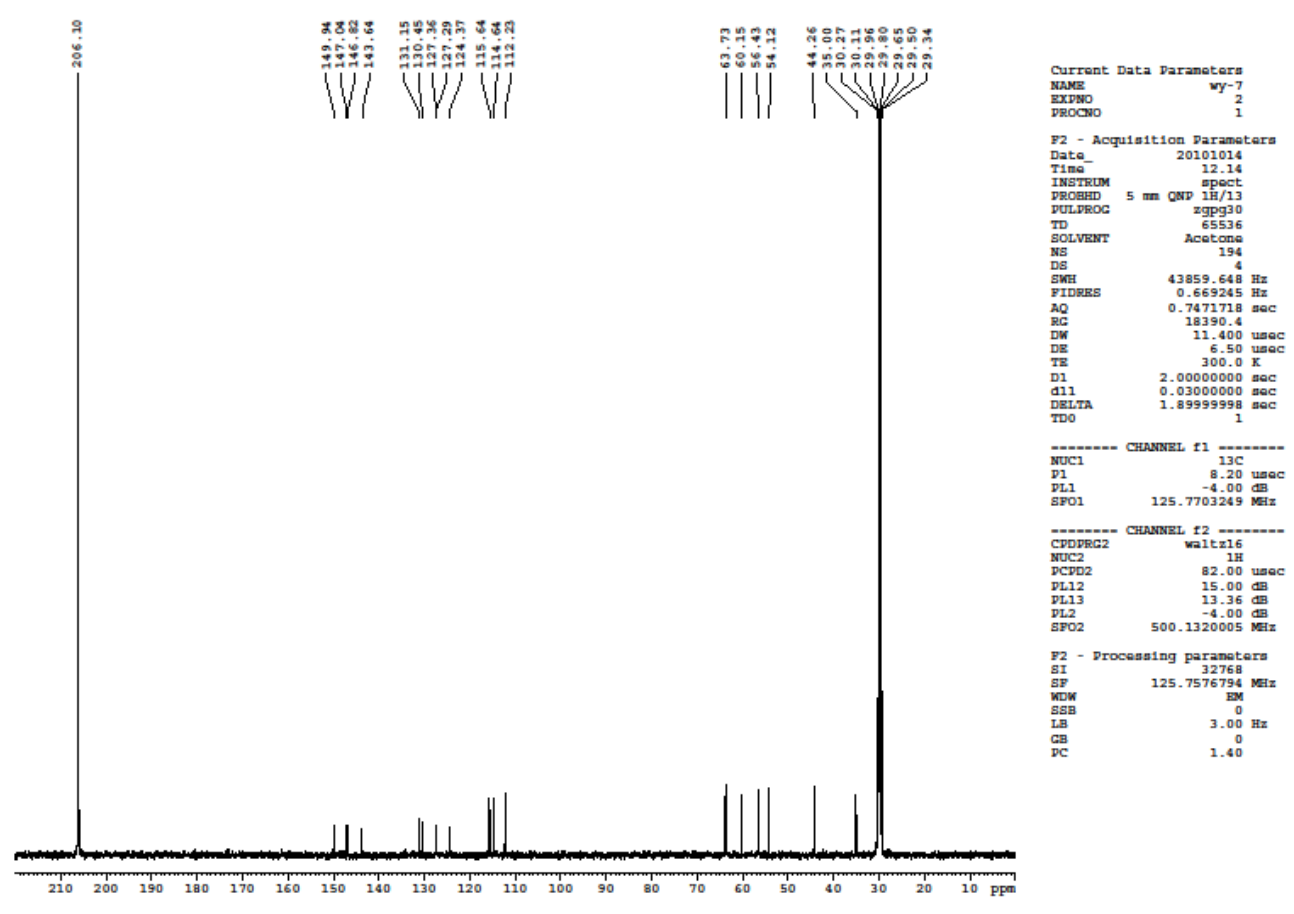

5. ESI-MS, ${ }^{1} \mathrm{H}-\mathrm{NMR}$ and ${ }^{13} \mathrm{C}-\mathrm{NMR}$ spectra of isoboldine. (A) ESI-MS $[\mathrm{M}+\mathrm{H}]^{+}$of isoboldine, (B) The ${ }^{1} \mathrm{H}-\mathrm{NMR}$ of isoboldine, (C) The ${ }^{13} \mathrm{C}-\mathrm{NMR}$ of isoboldine. Isoboldine: White amorphous powder $(\mathrm{MeOH}), \mathrm{ESI}-\mathrm{MS} \mathrm{m} / \mathrm{z}: 328.3[\mathrm{M}+\mathrm{H}]^{+} .{ }^{1} \mathrm{H}-\mathrm{NMR}$ (Acetone-d6, $\left.500 \mathrm{MHz}\right) \delta_{\mathrm{H}}: 7.84(1 \mathrm{H}, \mathrm{s}, \mathrm{H}-$ 11), $6.65(1 \mathrm{H}, \mathrm{s}, \mathrm{H}-8), 6.42(1 \mathrm{H}, \mathrm{s}, \mathrm{H}-3), 3.72\left(3 \mathrm{H}, \mathrm{s}, 10-\mathrm{OCH}_{3}\right), 3.45\left(3 \mathrm{H}, \mathrm{s}, 2-\mathrm{OCH}_{3}\right), 2.32(3 \mathrm{H}, \mathrm{s}$, - $\left.\mathrm{NCH}_{3}\right), 2.89 \sim 2.80(3 \mathrm{H}, \mathrm{m}, \mathrm{H}-6 \mathrm{a} \mathrm{H}-5), 2.72 \sim 2.41(2 \mathrm{H}, \mathrm{m}, \mathrm{H}-7), 2.28 \sim 2.21(2 \mathrm{H}, \mathrm{m}, \mathrm{H}-4),{ }^{13} \mathrm{C}-$ NMR (Acetone-d6, 125 MHZ) $\delta_{\mathrm{c}}$ : 143.6 (C-1), 149.9 (C-2), 112.2 (C-3), 130.5 (C-3a), 30.3 (C-4), 54.1 (C-5), 63.7 (C-6a), 35.0 (C-7), 131.2 (C-7a), 115.6 (C-8), 147.0 (C-9), 146.8 (C-10), 114.6 (C11), 127.3 (C-11a), 124.4 (C-11b), 127.4 (C-11c), 60.2 (C1-OMe), 56.4 (C10-OMe), 44.3 (N-Me).

A

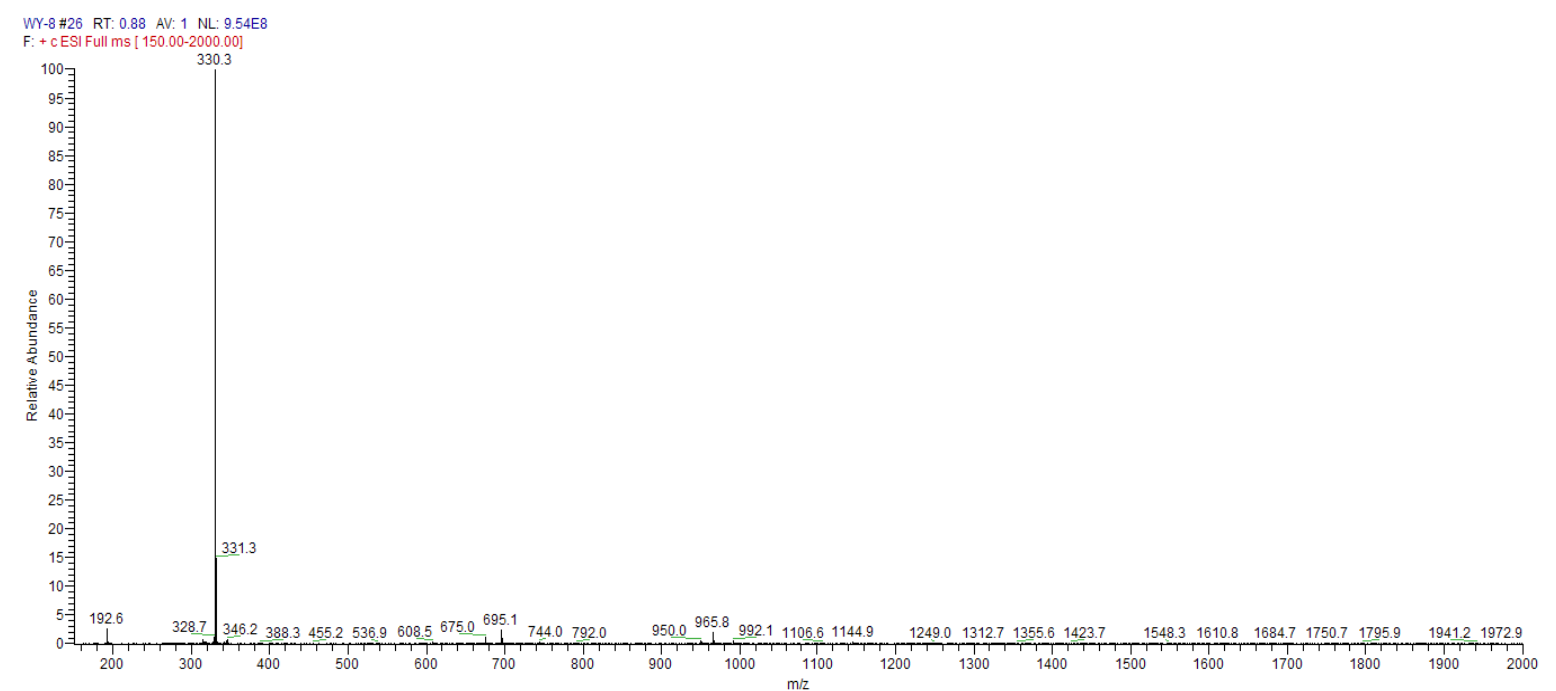




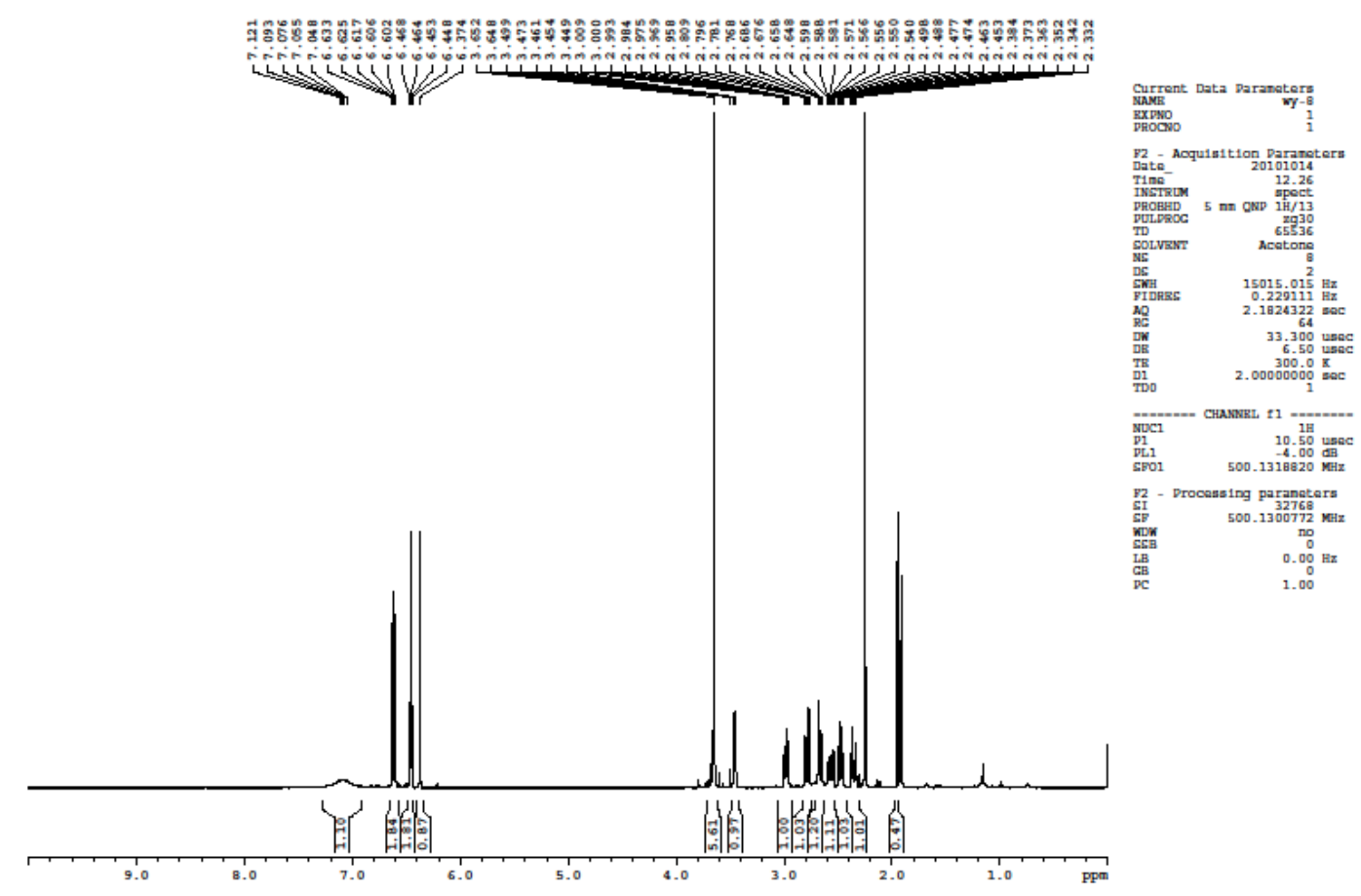

C
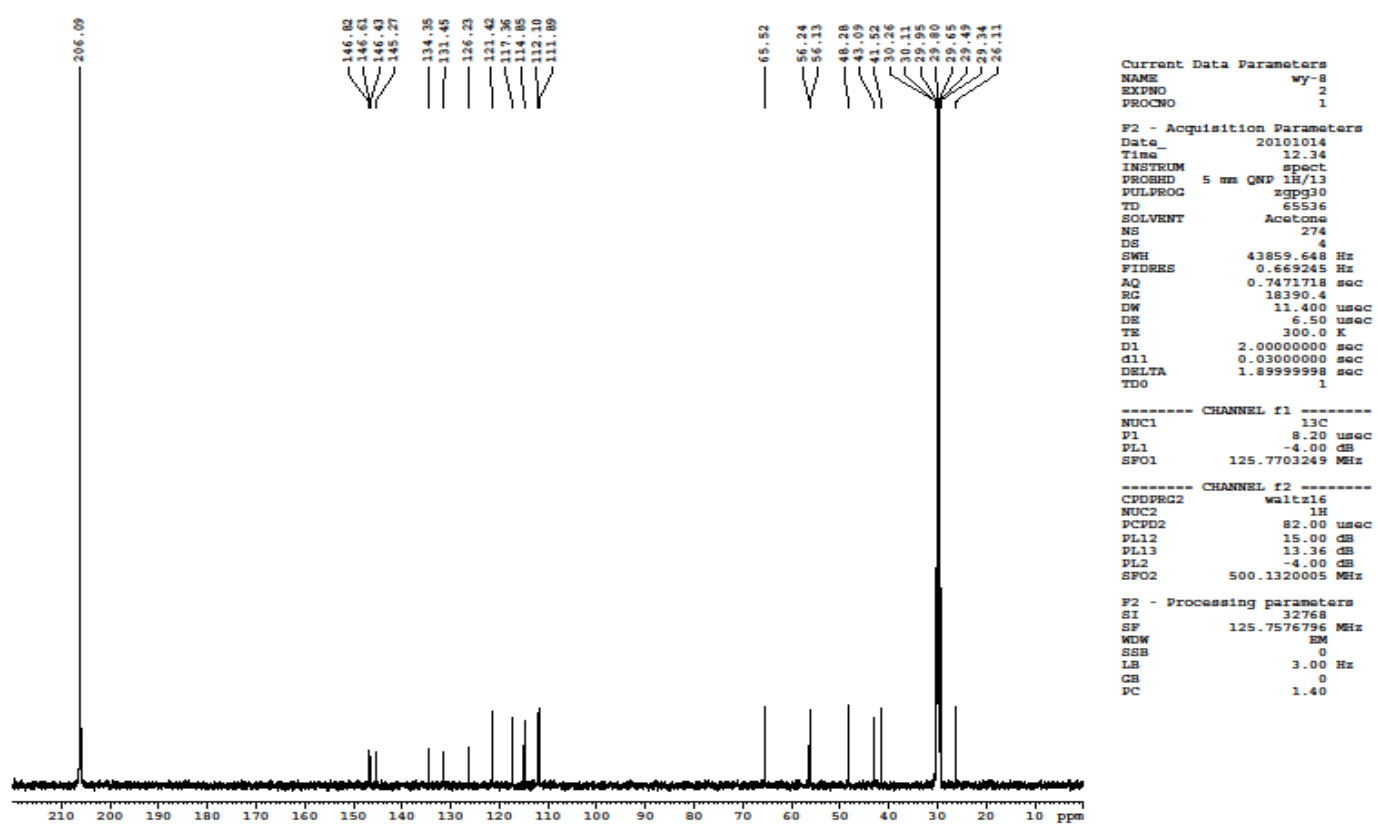

6. ESI-MS, ${ }^{1} \mathrm{H}$-NMR and ${ }^{13} \mathrm{C}$-NMR spectra of reticuline. (A) ESI-MS $[\mathrm{M}+\mathrm{H}]^{+}$of reticuline, (B) The ${ }^{1} \mathrm{H}-\mathrm{NMR}$ of reticulie, (C) The ${ }^{13} \mathrm{C}-\mathrm{NMR}$ of reticuline. Reticuline: Light yellow amorphous powder $(\mathrm{MeOH})$, ESI-MS m/z : $330.3[\mathrm{M}+\mathrm{H}]^{+} .{ }^{1} \mathrm{H}-\mathrm{NMR}$ (Acetone- $\left.\mathrm{d}_{6}, 500 \mathrm{MHz}\right) \delta_{\mathrm{H}}$ : $6.63(1 \mathrm{H}, \mathrm{s}, \mathrm{H}-5), 6.60(1 \mathrm{H}, \mathrm{dd}, \mathrm{J}=2.0 \mathrm{~Hz}, 4.0 \mathrm{~Hz}, \mathrm{H}-10), 6.46(1 \mathrm{H}, \mathrm{d}, \mathrm{J}=2.0 \mathrm{~Hz}, \mathrm{H}-14), 6.45$ $(1 \mathrm{H}, \mathrm{d}, \mathrm{J}=2.5 \mathrm{~Hz}, \mathrm{H}-11), 6.37(1 \mathrm{H}, \mathrm{s}, \mathrm{H}-8), 3.65\left(6 \mathrm{H}, \mathrm{d}, \mathrm{J}=2.0 \mathrm{~Hz}, \mathrm{C}_{6}\right.$ and $\left.\mathrm{C} 12-\mathrm{OCH} 3\right), 3.46$ 
$(1 \mathrm{H}, \mathrm{t}, \mathrm{J}=6.0 \mathrm{~Hz}, \mathrm{H}-1), 3.01 \sim 2.96$ and $2.59 \sim 2.54(2 \mathrm{H}, \mathrm{m}, \mathrm{H}-3 \mathrm{a}), 2.81 \sim 2.77(1 \mathrm{H}, \mathrm{dd}, \mathrm{J}=6.5 \mathrm{~Hz}$, $\left.14.0 \mathrm{~Hz}, \mathrm{H}-1^{\mathrm{a}}-1\right), 2.69 \sim 2.65(1 \mathrm{H}, \mathrm{dd}, \mathrm{J}=5.0 \mathrm{~Hz}, 14.0 \mathrm{~Hz}, \mathrm{H}-1 \mathrm{a}-2), 2.49 \sim 2.33(2 \mathrm{H}, \mathrm{m}, \mathrm{H}-4), 2.25$ (3H, s, N- CH3). 13C-NMR (Acetone-d6, $125 \mathrm{MHz}$ ) 8C: 65.5 (C-1), 41.5 (C-1a), 48.3 (C-3), 26.1 (C-4), 126.2 (C-4a), 112.1 (C-5), 146.4 (C-6), 145.3 (C-7), 114.9 (C-8), 131.5 (C-8a), 134.4 (C-9), 121.4 (C-10), 111.9 (C-11), 146.6 (C-12), 146.8 (C-13), 117.4 (C-14), 56.1 (C6-OMe), 56.2 (C12$\mathrm{OMe}), 43.1(\mathrm{~N}-\mathrm{Me})$.

A

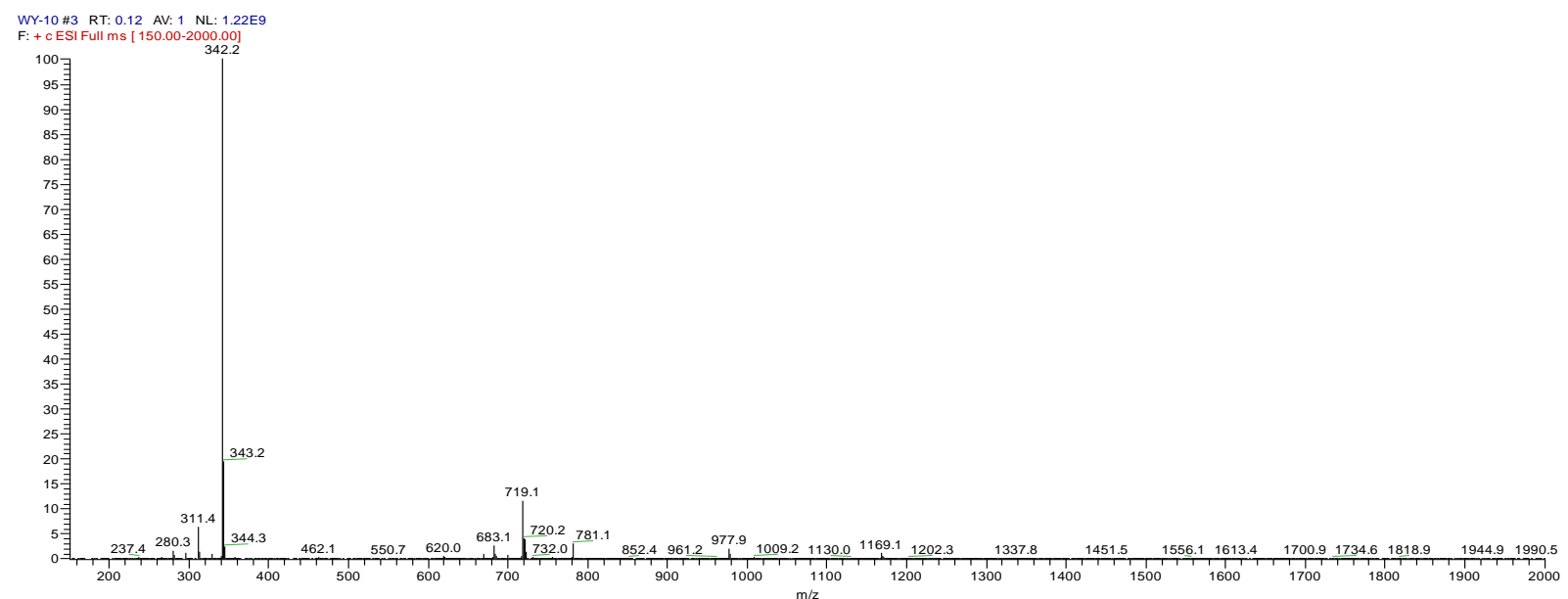

B

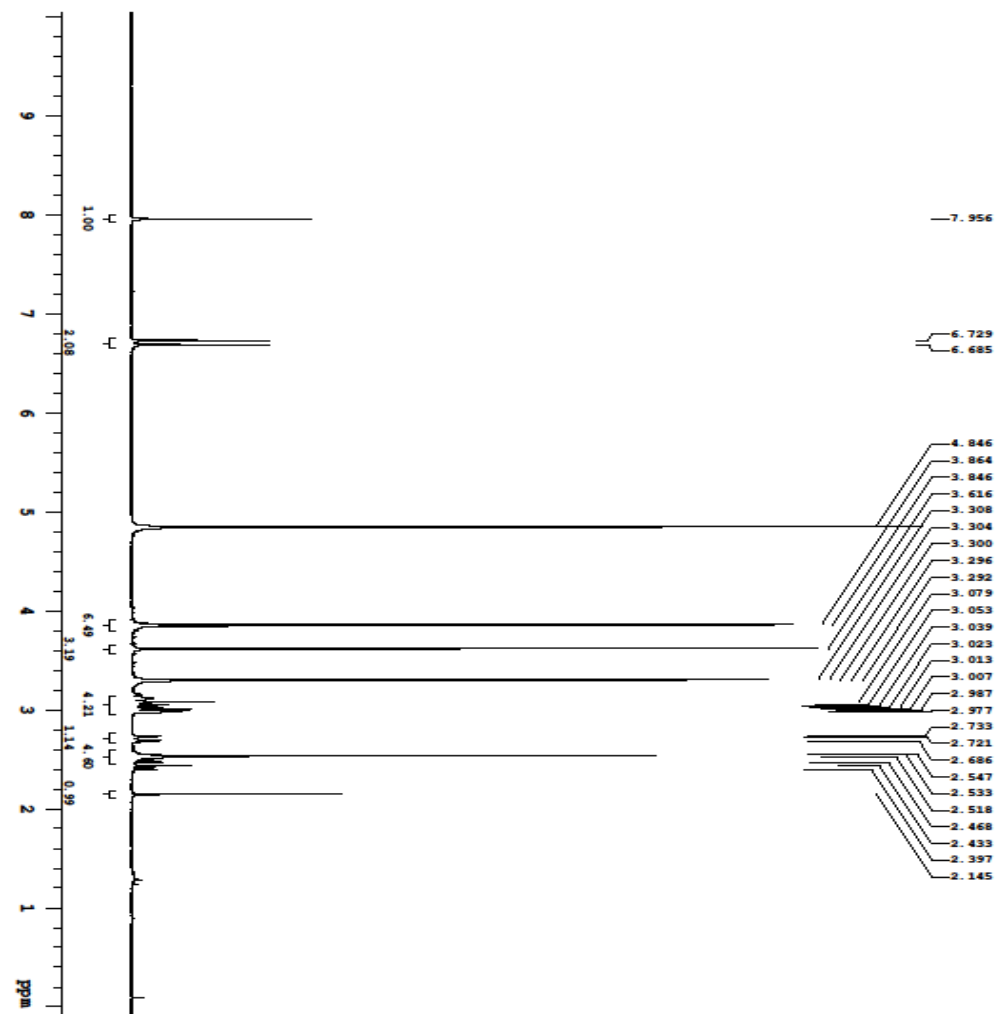




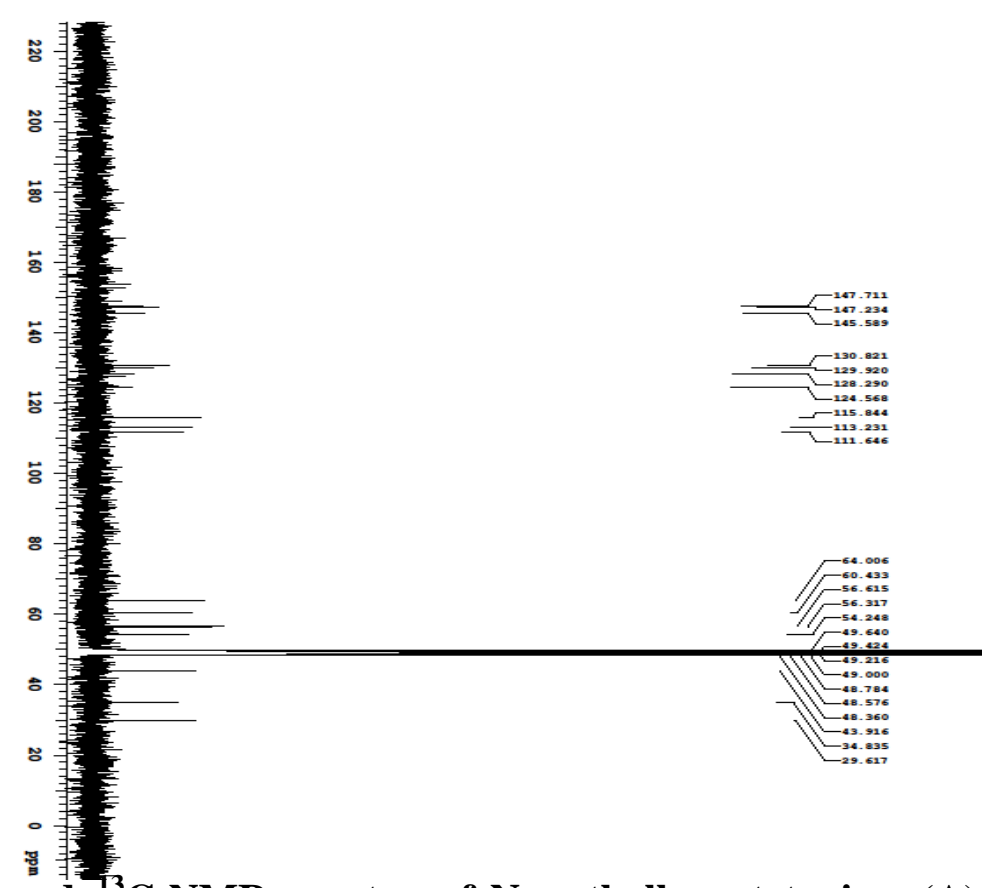

7. ESI-MS, ${ }^{1} \mathrm{H}-\mathrm{NMR}$ and ${ }^{13} \mathrm{C}-\mathrm{NMR}$ spectra of $\mathrm{N}$-methyllaurotetanine. (A) ESI-MS $[\mathrm{M}+\mathrm{H}]^{+}$ of N-methyllaurotetanine, (B) The ${ }^{1} \mathrm{H}-\mathrm{NMR}$ of $\mathrm{N}$-methyllaurotetanine, (C) The ${ }^{13} \mathrm{C}-\mathrm{NMR}$ of $\mathrm{N}$ methyllaurotetanine. N-methyllaurotetanine: Light vellow amorphous powder $(\mathrm{MeOH})$, ESI-MS m/z: $342.2\lceil\mathrm{M}+\mathrm{H}\rceil+.1 \mathrm{H}-\mathrm{NMR}(\mathrm{CD} 3 \mathrm{OD}, 500 \mathrm{MHz}) \delta \mathrm{H}: 7.96(1 \mathrm{H}, \mathrm{s}, \mathrm{H}-11), 6.73(1 \mathrm{H}, \mathrm{s}, \mathrm{H}-8), 6.69$

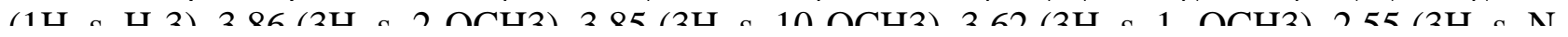
CH3) , $3.08 \sim 2.98(4 \mathrm{H}, \mathrm{m}, \mathrm{H}-5,7), 2.15 \sim 2.51(2 \mathrm{H}, \mathrm{m}, \mathrm{H}-4) .13 \mathrm{C}-\mathrm{NMR}$ (CD3OD, $125 \mathrm{MHz}) \delta \mathrm{C}$ :

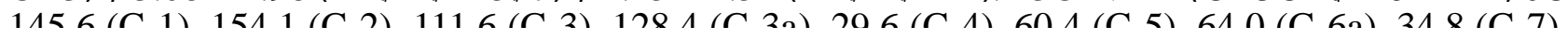
128.3 (C-7a), 115.8 (C-8) , 147.7 (C-9), 147.2 (C-10), 113.2 (C-11), 130.8 (C-11a), 129.9 (C-11b), 124.6 (C-11c), 56.6 (C1-OMe), 54.2 (C2-OMe), 56.3 (C10-OMe), 43.9 (N-Me).

A

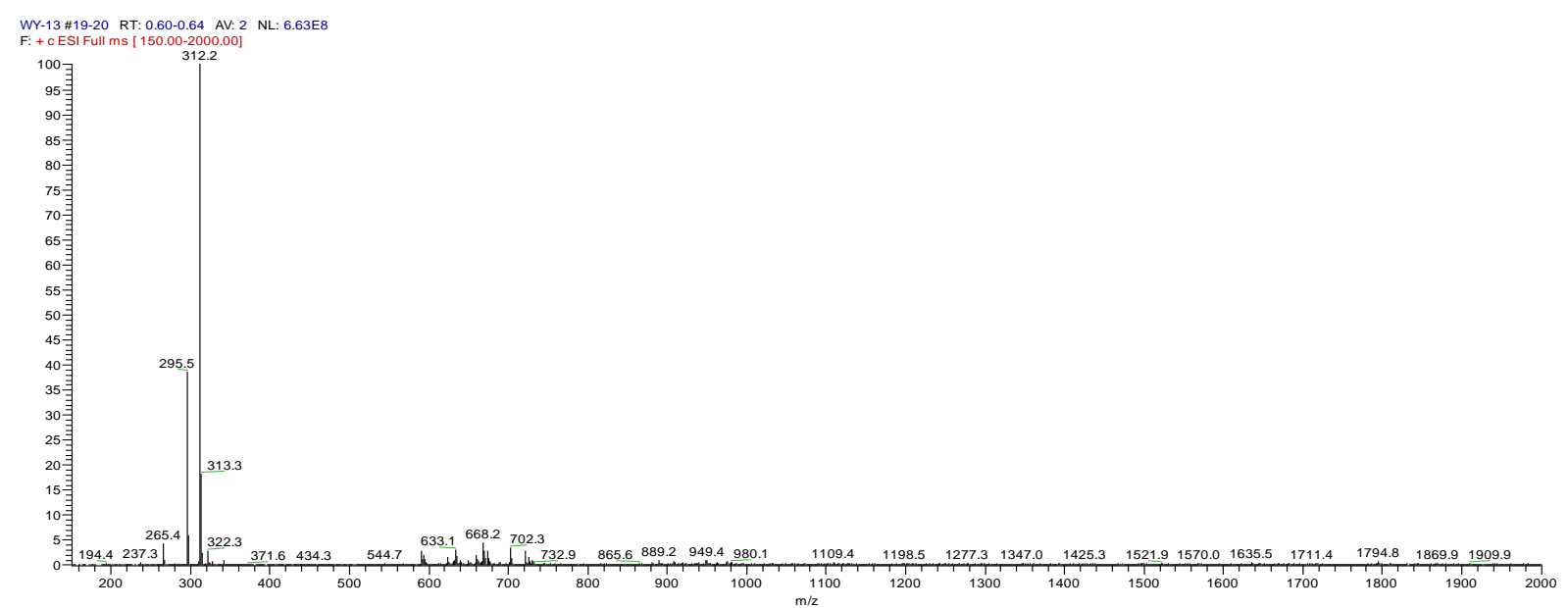




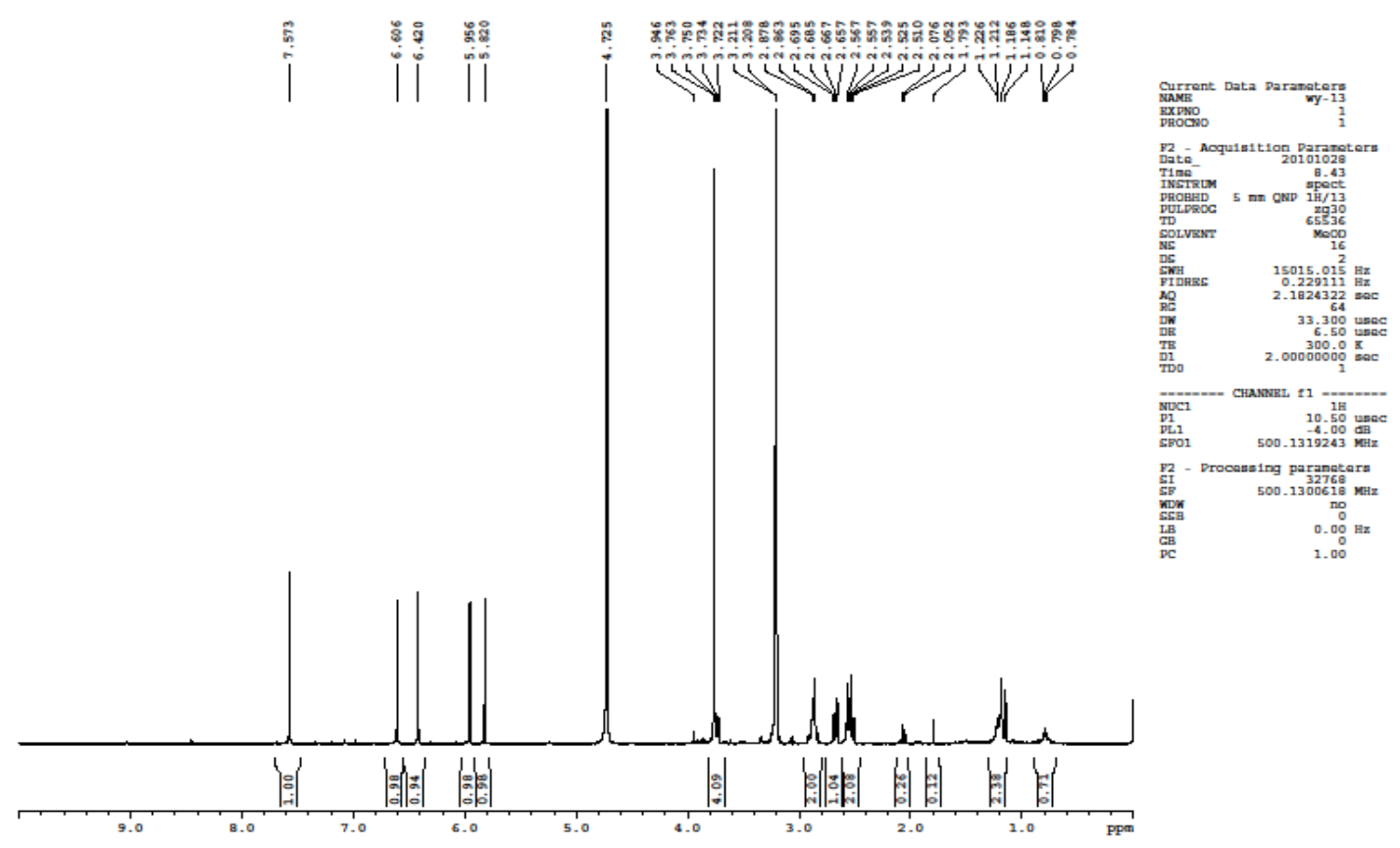

C

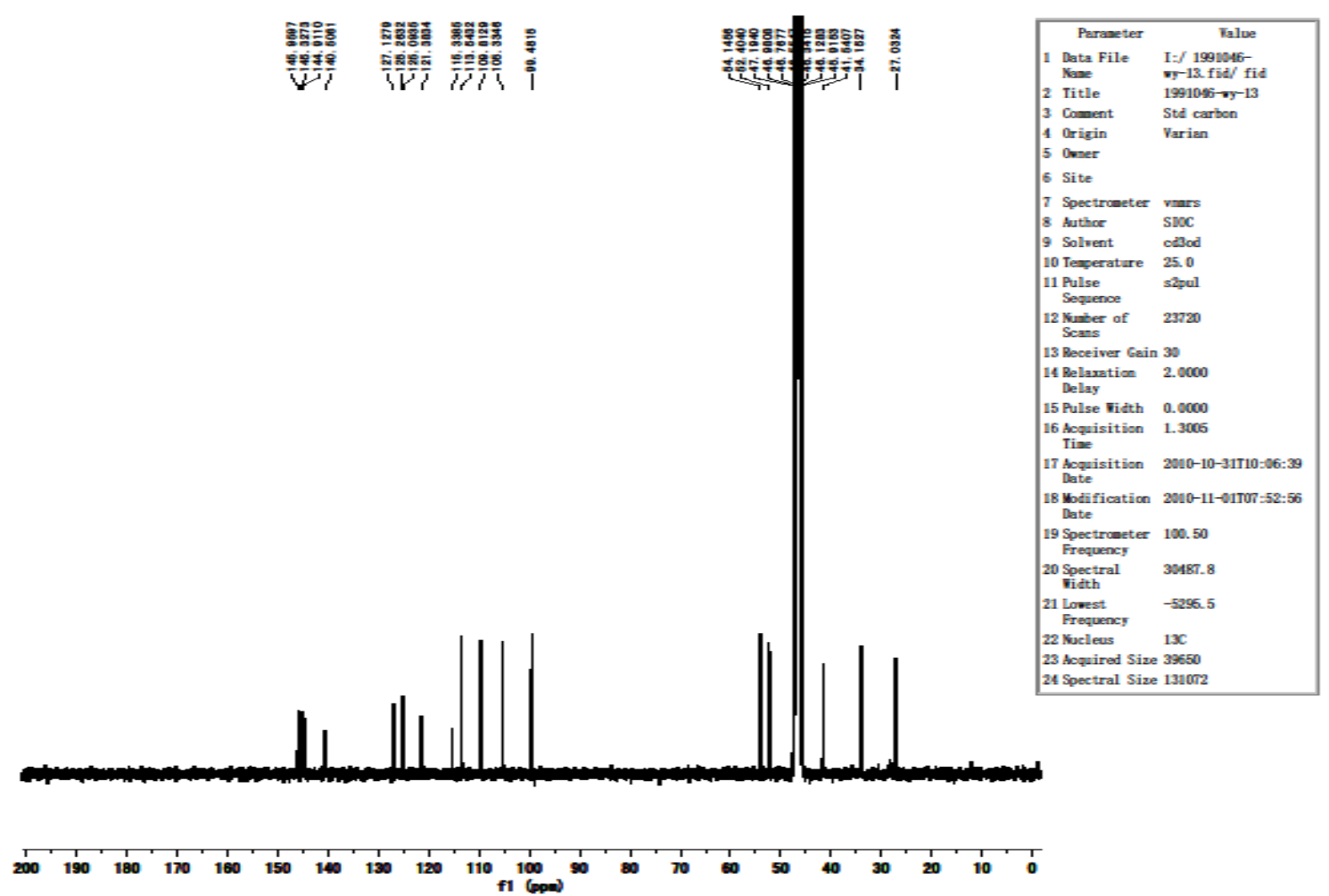

8. ESI-MS, ${ }^{1} \mathrm{H}-\mathrm{NMR}$ and ${ }^{13} \mathrm{C}$-NMR spectra of actinodaphine. (A) ESI-MS $[\mathrm{M}+\mathrm{H}]^{+}$of actinodaphine, (B) The ${ }^{1} \mathrm{H}-\mathrm{NMR}$ of actinodaphine (C) The ${ }^{13} \mathrm{C}-\mathrm{NMR}$ of actinodaphine. Actinodaphnine: White amorphous powder $(\mathrm{MeOH})$, ESI-MS m/z: $312.2[\mathrm{M}+\mathrm{H}]^{+}$. ${ }^{1} \mathrm{H}-\mathrm{NMR}$ $\left(\mathrm{CD}_{3} \mathrm{OD}, 500 \mathrm{MHz}\right) \delta_{\mathrm{H}}: 7.58(1 \mathrm{H}, \mathrm{s}, \mathrm{H}-11), 6.61(1 \mathrm{H}, \mathrm{s}, \mathrm{H}-8), 6.42(1 \mathrm{H}, \mathrm{s}, \mathrm{H}-3), 5.82$ and 5.92 ( each $\left.1 \mathrm{H}, \mathrm{d}, \mathrm{J}=1.4 \mathrm{~Hz}, 1-\mathrm{OCH}_{2} \mathrm{O}-2\right), 3.76\left(3 \mathrm{H}, \mathrm{s}, 3-\mathrm{OCH}_{3}\right), 2.68(1 \mathrm{H}, \mathrm{dd}, \mathrm{J}=5.0 \mathrm{~Hz}, 9.0 \mathrm{~Hz}, \mathrm{H}-6 \mathrm{a})$, 
$2.87(2 \mathrm{H}, \mathrm{m}, \mathrm{H}-7), 2.55(2 \mathrm{H}, \mathrm{m}, \mathrm{H}-5), 1.21(2 \mathrm{H}, \mathrm{m}, \mathrm{H}-4) .{ }^{13} \mathrm{C}-\mathrm{NMR}\left(\mathrm{CD}_{3} \mathrm{OD}, 125 \mathrm{MHz}\right) \delta_{\mathrm{C}}: 145.9$ (C-1), 145.3 (C-2), 105.3 (C-3), 125.3 (C-3a), 27.0 (C-4), 41.5 (C-5), 52.4 (C-6a), 34.2 (C-7), 127.1 (C-7a), 113.5 (C-8), 140.5 (C-9), 144.9 (C-10), 113.5(C-11), 125.1 (C-11a), 121.4 (C-11b), 115.3 (C-11c), 54.1 (C10-OMe), 99.5 (-O-CH2-O-).

A

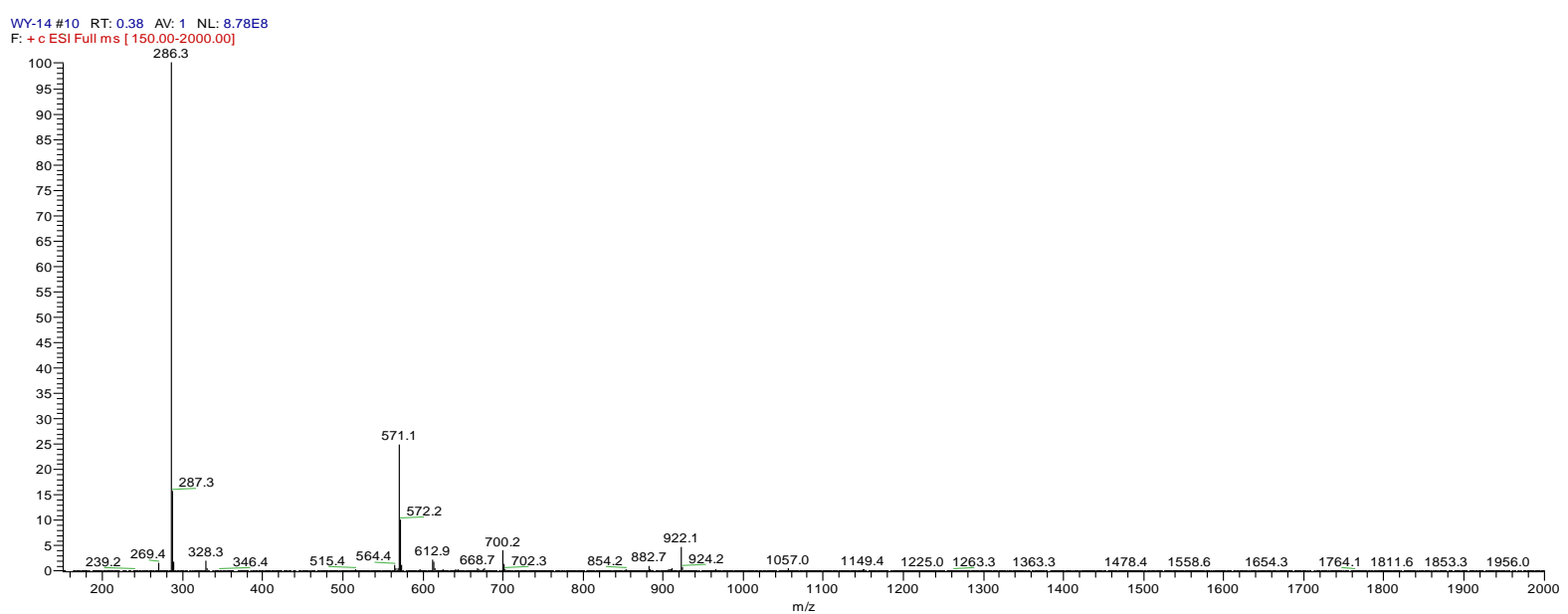

B

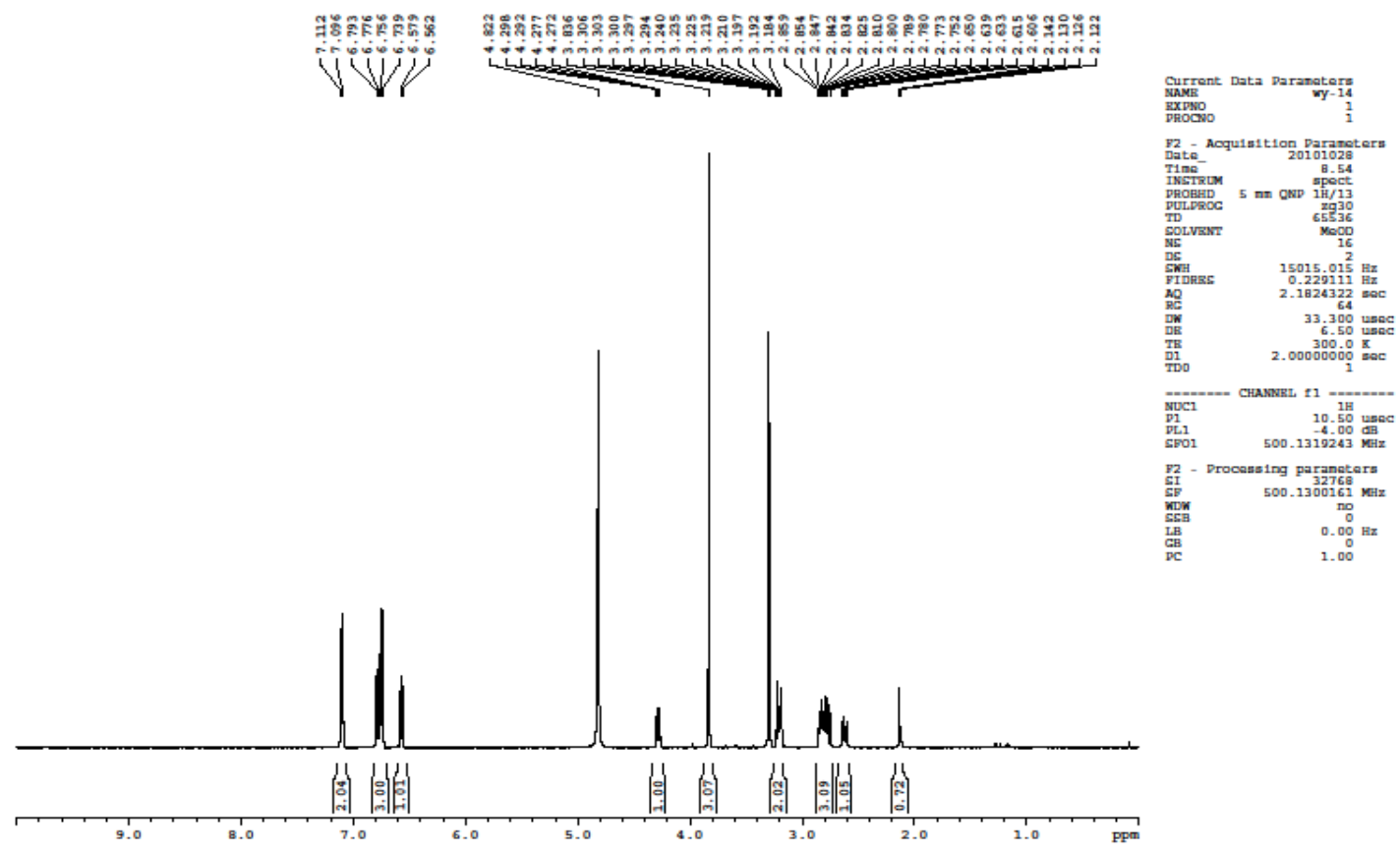


C

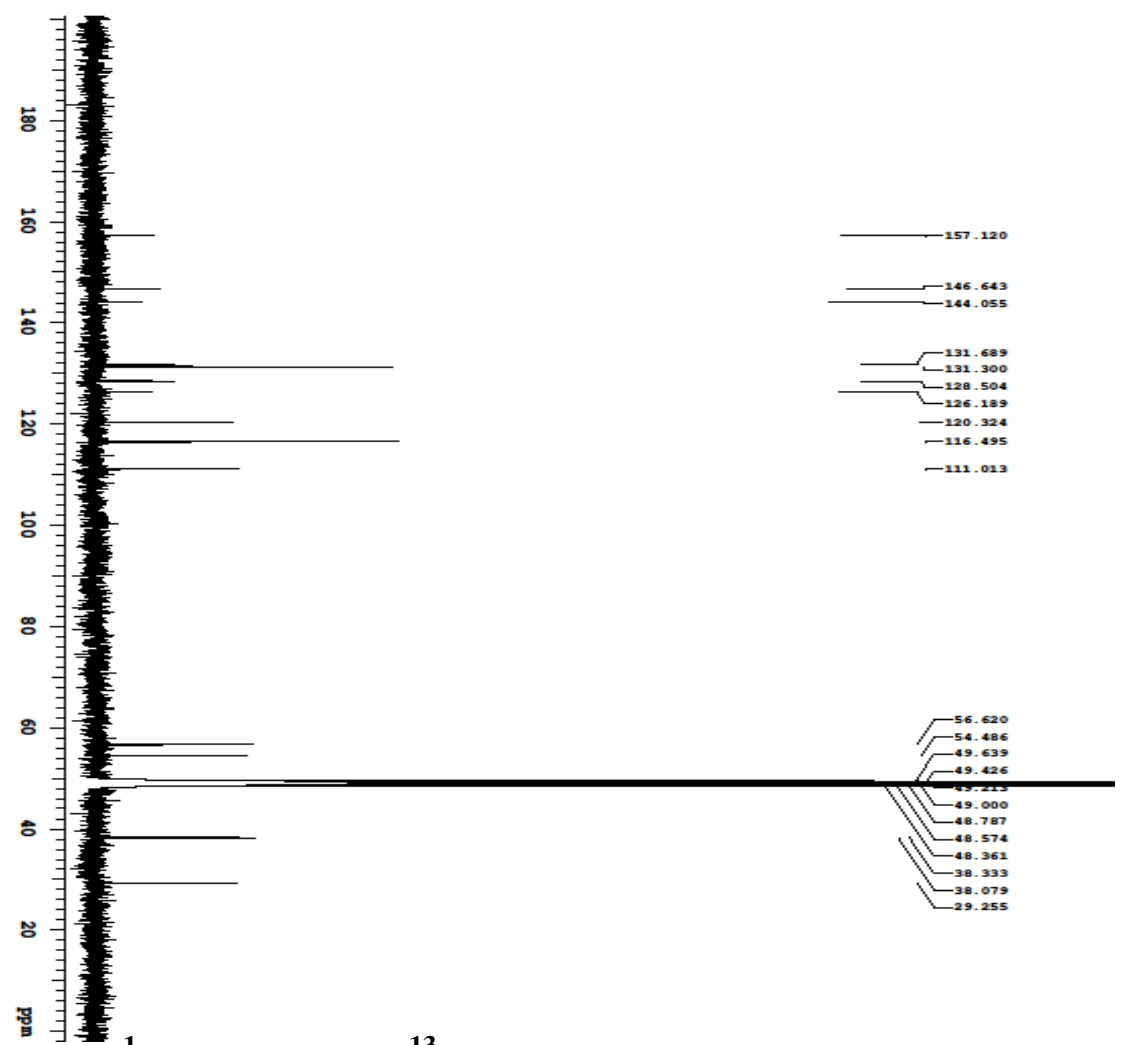

9. ESI-MS, ${ }^{1}$ H-NMR and ${ }^{13} \mathrm{C}-\mathrm{NMR}$ spectra of norjuziphine. (A) ESI-MS $[\mathrm{M}+\mathrm{H}]^{+}$of norjuziphine, (B) The ${ }^{1} \mathrm{H}-\mathrm{NMR}$ of norjuziphine, (C) The ${ }^{13} \mathrm{C}-\mathrm{NMR}$ of norjuziphine. Norjuziphine: Colorless crystal $(\mathrm{MeOH})$, ESI-MS m/z: $286.3[\mathrm{M}+\mathrm{H}]^{+} .{ }^{1} \mathrm{H}-\mathrm{NMR}\left(\mathrm{CD}_{3} \mathrm{OD}, 500 \mathrm{MHz}\right) \delta \mathrm{H}: 7.10$ $(2 \mathrm{H}, \mathrm{d}, \mathrm{J}=8.0 \mathrm{~Hz}, \mathrm{H}-10,14), 6.75(2 \mathrm{H}, \mathrm{d}, \mathrm{J}=8.5 \mathrm{~Hz}, \mathrm{H}-11.13), 6.68(1 \mathrm{H}, \mathrm{d}, \mathrm{J}=8.5 \mathrm{~Hz}, \mathrm{H}-5), 6.57$ $(1 \mathrm{H}, \mathrm{d}, \mathrm{J}=8.5 \mathrm{~Hz} . \mathrm{H}-6), 3.84$ (3H. s, 7-OMe), $4.28(1 \mathrm{H}, \mathrm{dd}, \mathrm{J}=3.0 \mathrm{~Hz}, 10.0 \mathrm{~Hz}, \mathrm{H}-1), 3.18 \sim 3.24$ $(2 \mathrm{H}, \mathrm{m}, \mathrm{H}-1 \mathrm{a}), 2.61 \sim 2.86(4 \mathrm{H}, \mathrm{m}, \mathrm{H}-3,4) .{ }^{13} \mathrm{C}-\mathrm{NMR}\left(\mathrm{CD}_{3} \mathrm{OD}, 125 \mathrm{MHz}\right) \delta \mathrm{C}: 38.3(\mathrm{C}-1), 38.1(\mathrm{C}-$ 1a), 54.5 (C-3), 29.3 ( C-4), 131.7 (C-4a), 120.3 (C-5), 111.0 (C-6), 146.6 (C-7), 144.1 (C-8), 126.2 (C-8a), 131.3 (C-9), 128.5 (C-10), 116.5 (C-11), 157.1 (C-12), 116.5 (C-13), 128.5 (C-14), 56.6 (C7-OMe).

A

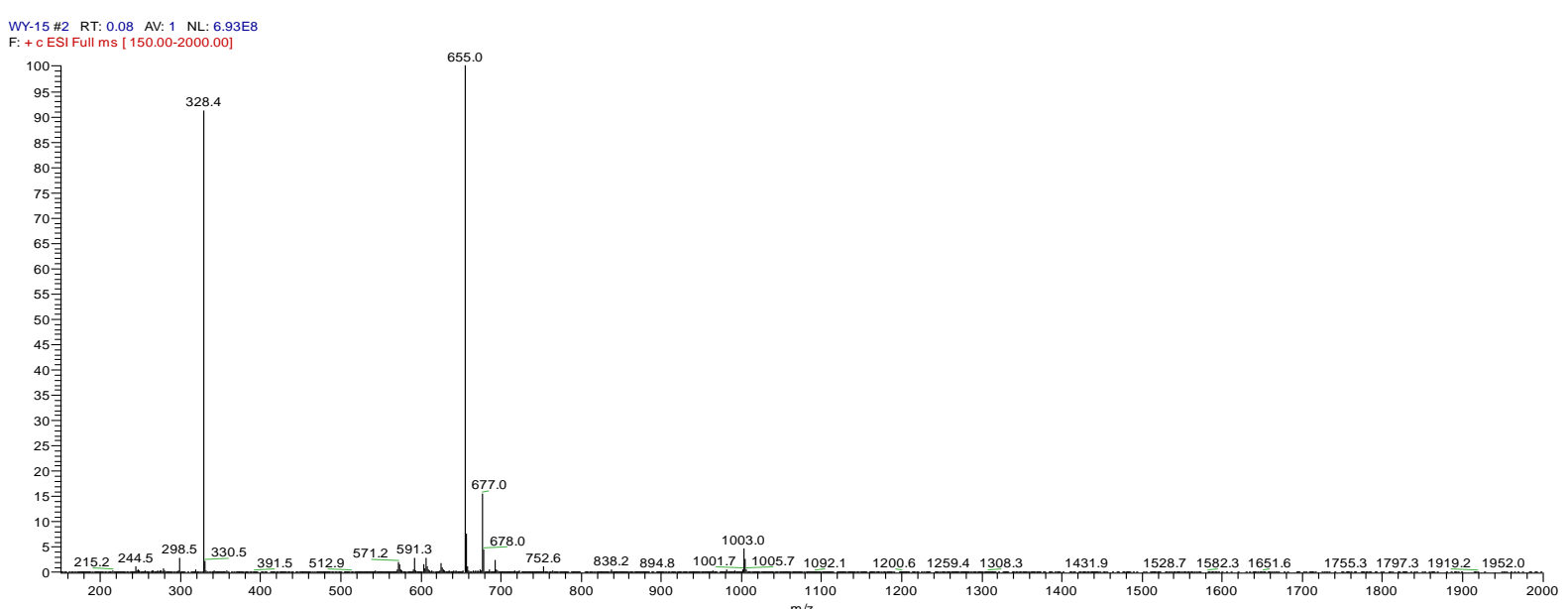




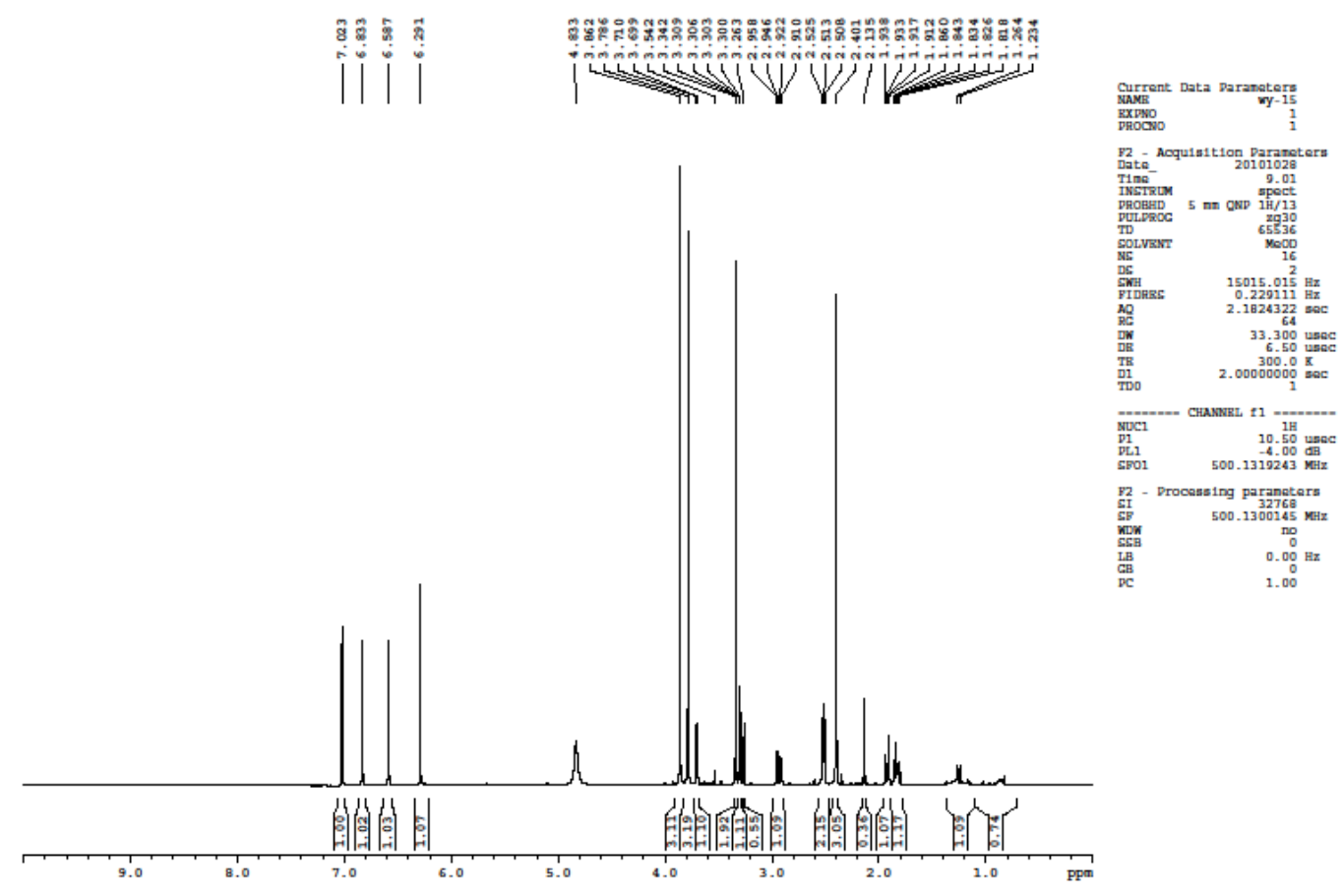

C

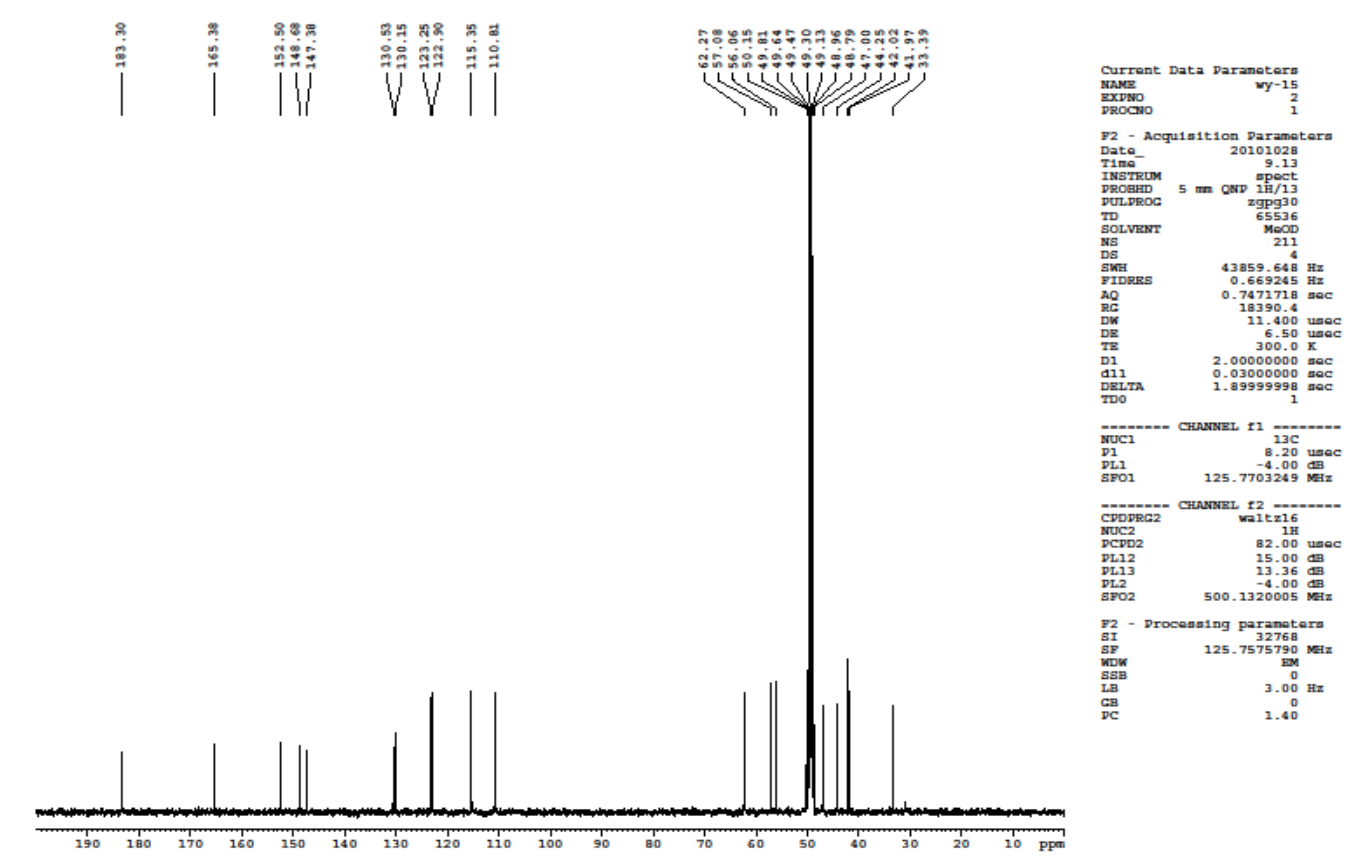

10. ESI-MS, ${ }^{1} \mathrm{H}-\mathrm{NMR}$ and ${ }^{13} \mathrm{C}$-NMR spectra of pallidine. (A) ESI-MS $[\mathrm{M}+\mathrm{H}]^{+}$of pallidine (B) The ${ }^{1} \mathrm{H}-\mathrm{NMR}$ of pallidine (C) The ${ }^{13} \mathrm{C}-\mathrm{NMR}$ of pallidine. Pallidine: White amorphous powder $(\mathrm{MeOH})$, ESI-MS m/z: $328.4[\mathrm{M}+\mathrm{H}]^{+} .{ }^{1} \mathrm{H}-\mathrm{NMR}\left(\mathrm{CD}_{3} \mathrm{OD}, 500 \mathrm{MHz}\right) \delta_{\mathrm{H}}: 6.83(1 \mathrm{H}, \mathrm{s}, \mathrm{H}-1)$, $7.02(1 \mathrm{H}, \mathrm{s}, \mathrm{H}-4), 6.59(1 \mathrm{H}, \mathrm{s}, \mathrm{H}-5), 6.29(1 \mathrm{H}, \mathrm{s}, \mathrm{H}-8), 3.86(3 \mathrm{H}, \mathrm{s}, 3-\mathrm{OMe}), 3.79$ (3H, s, 6-OMe), $2.40(3 \mathrm{H}, \mathrm{s}, \mathrm{N}-\mathrm{Me}), 3.70(1 \mathrm{H}, \mathrm{d}, \mathrm{J}=5.5 \mathrm{~Hz}, \mathrm{H}-9), 3.01(1 \mathrm{H}, \mathrm{d}, \mathrm{J}=18.0 \mathrm{~Hz}, \mathrm{Hb}-10), 2.93(1 \mathrm{H}, \mathrm{dd}, \mathrm{J}$ $=6.0,18.0 \mathrm{~Hz}, \mathrm{Ha}-10), 2.53 \sim 2.50(2 \mathrm{H}, \mathrm{m}, \mathrm{H}-16), 1.94 \sim 1.91(1 \mathrm{H}, \mathrm{m}, \mathrm{Ha}-15), 1.86 \sim 1.81(1 \mathrm{H}, \mathrm{m}$, 
Hb-15), ${ }^{13} \mathrm{C}-\mathrm{NMR}\left(\mathrm{CD}_{3} \mathrm{OD}, 125 \mathrm{MHz}\right) \delta \mathrm{c}: 110.8$ (C-1), 147.4 (C-2), 148.7 (C-3), 115 (C-4), 122.9 (C-5), 152.5 (C-6), 183.3 (C-7), 123.3 (C-8), 62.3 (C-9), 33.4 (C-10), 130.2 (C-11), 130.5 (C-12), 44.3 (C-13), 165.4 (C-14, 42.0 (C-15), 47.0 (C-16), 57.1 (-OMe), 54.1 (-OMe), 42.0 (NMe).

A

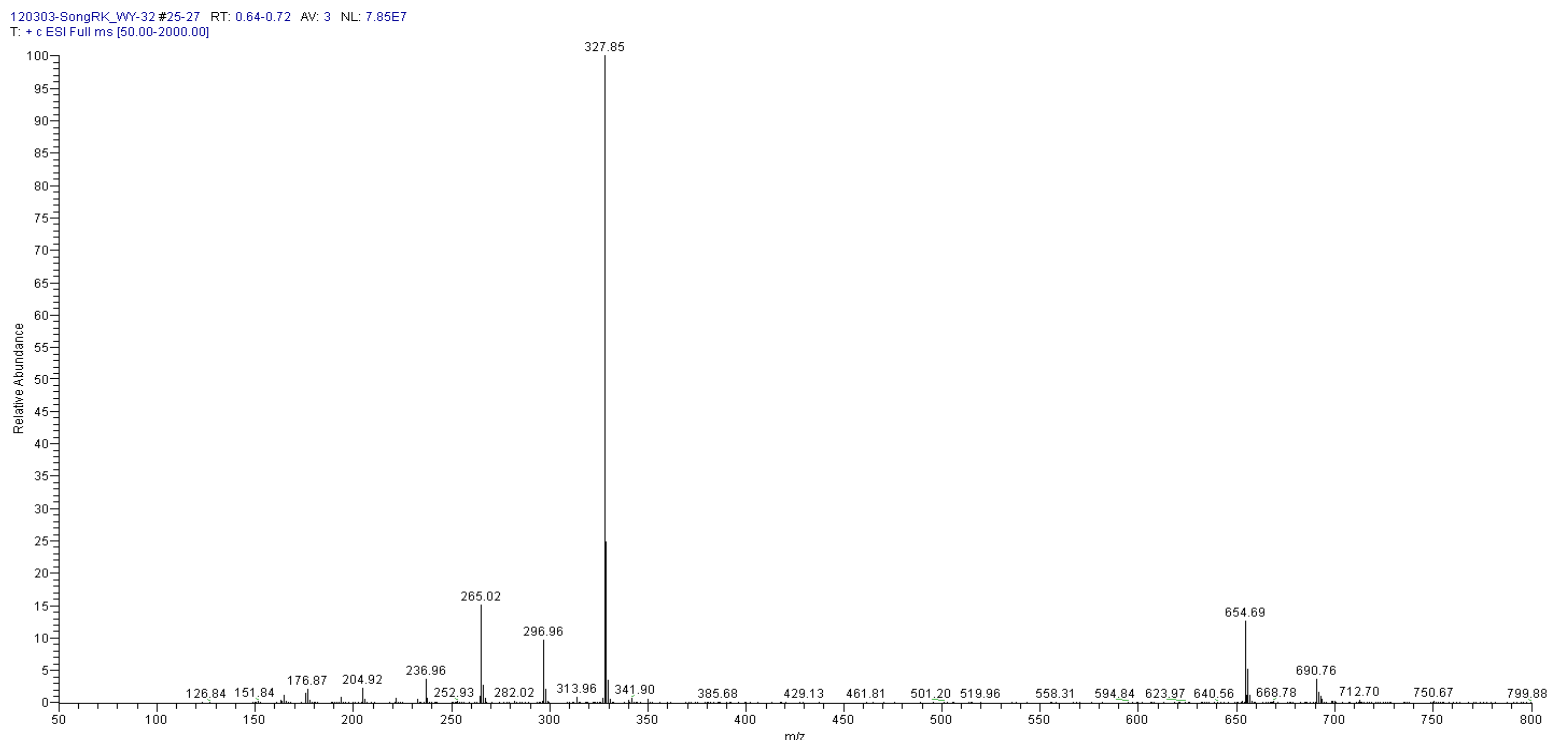

B

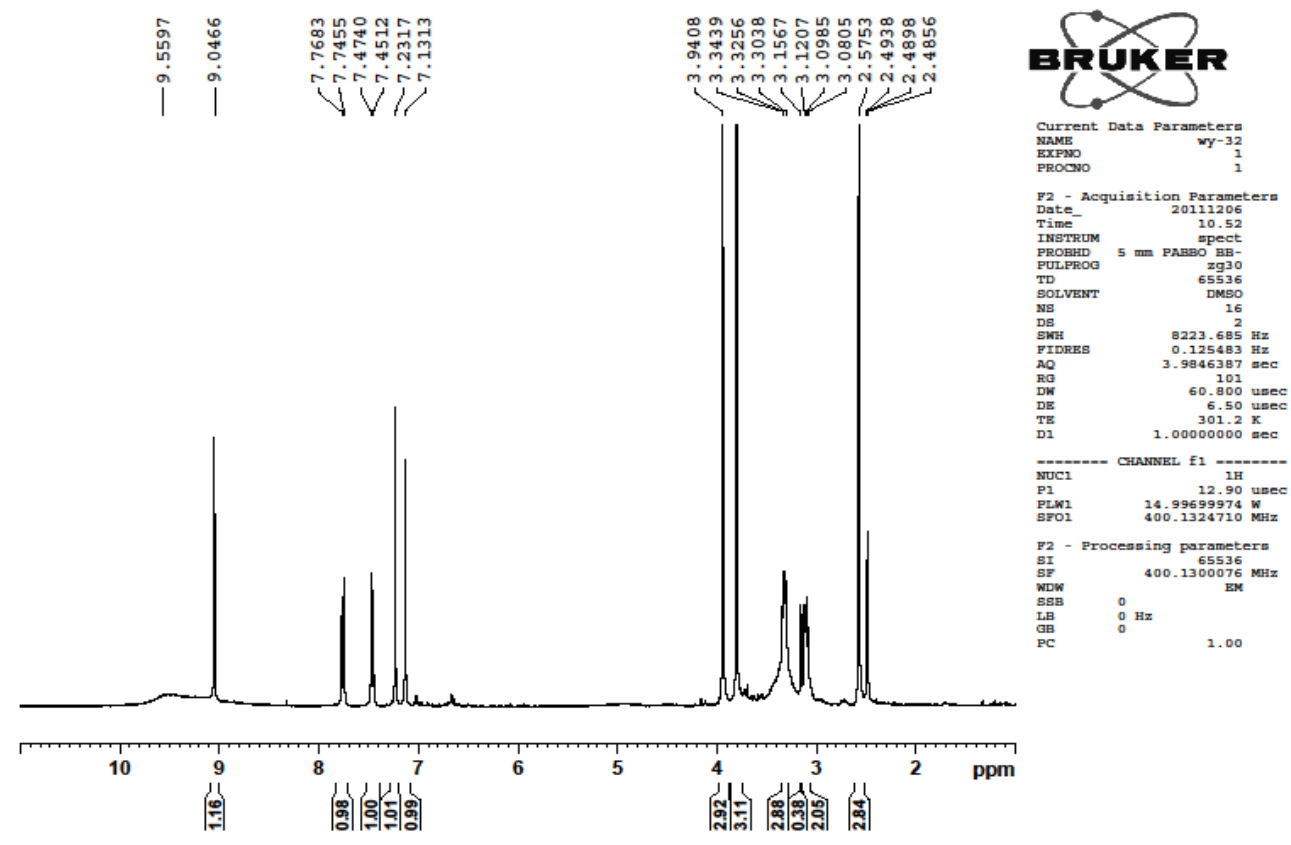




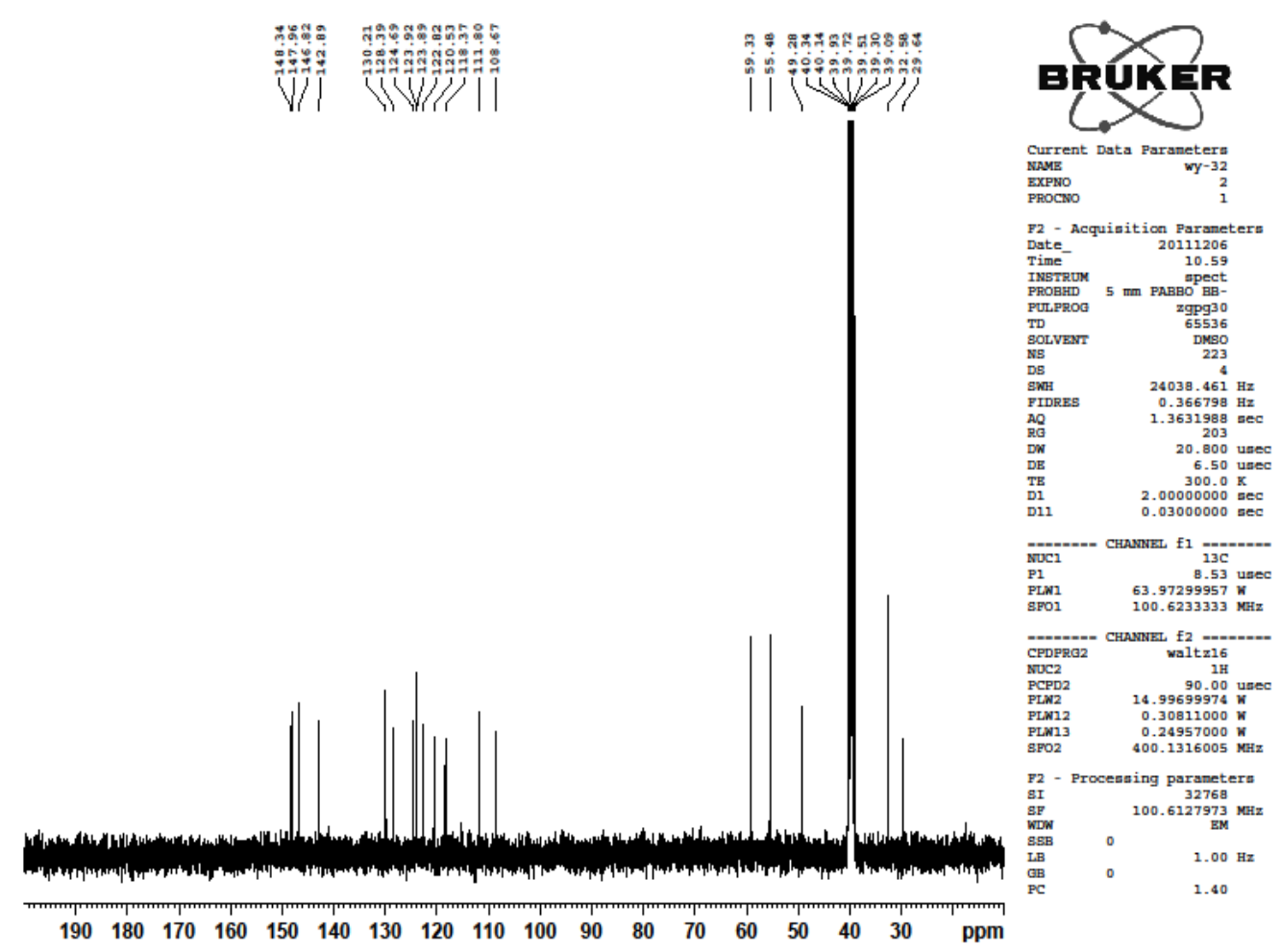

11. ESI-MS, ${ }^{1} \mathrm{H}-\mathrm{NMR}$ and ${ }^{13} \mathrm{C}$-NMR spectra of secoboldine. (A) ESI-MS $\left.[\mathrm{M}+\mathrm{H}]\right]^{+}$of secoboldine, (B) The ${ }^{1} \mathrm{H}-\mathrm{NMR}$ of secoboldine, (C) The ${ }^{13} \mathrm{C}-\mathrm{NMR}$ of secoboldine. Secoboldine: Yellowish-brown amorphous powder $(\mathrm{MeOH})$, ESI-MS m/z: $327.9[\mathrm{M}+\mathrm{H}]^{+} .{ }^{1} \mathrm{H}-\mathrm{NMR}\left(\mathrm{DMSO}-\mathrm{d}_{6}, 400 \mathrm{MHz}\right) \delta_{\mathrm{H}}: 9.05$ (1H, s, H-5), 7.75 (1H, d, J = 9.12 Hz, H-10), $7.47(1 \mathrm{H}, \mathrm{d}, \mathrm{J}=9.1 \mathrm{~Hz}, \mathrm{H}-9), 7.23(1 \mathrm{H}, \mathrm{s}, \mathrm{H}-8), 7.13$ $(1 \mathrm{H}, \mathrm{s}, \mathrm{H}-2), 3.94(3 \mathrm{H}, \mathrm{s}, 6-\mathrm{OMe}), 3.80(3 \mathrm{H}, \mathrm{s}, 4-\mathrm{OMe}), 2.58(3 \mathrm{H}, \mathrm{s}, \mathrm{N}-\mathrm{Me}), 3.33(2 \mathrm{H}, \mathrm{m}, \mathrm{H}-11)$, $3.10(2 \mathrm{H}, \mathrm{m}, \mathrm{H}-12) ;{ }^{13} \mathrm{C}-\mathrm{NMR}\left(\mathrm{DMSO}-\mathrm{d}_{6}, 100 \mathrm{MHz}\right) \delta_{\mathrm{C}}: 130.2(\mathrm{C}-1), 118.4(\mathrm{C}-2), 142.9(\mathrm{C}-3)$, 146.8 (C-4). 124.7 (C-4a), 108.7 (C-5), 111.0 (C-5a), 148.3 (C-6), 148.0 (C-7), 111.8 (C-8), 128.4 (C-8a), 123.9 (C-9), 120.5 (C-10), 123.9 (C-10a), 29.6 (C-11), 49.3 (C-12), 59.3 (C4-OMe), 55.5 (C6-OMe), 32.6 (N-Me).

A

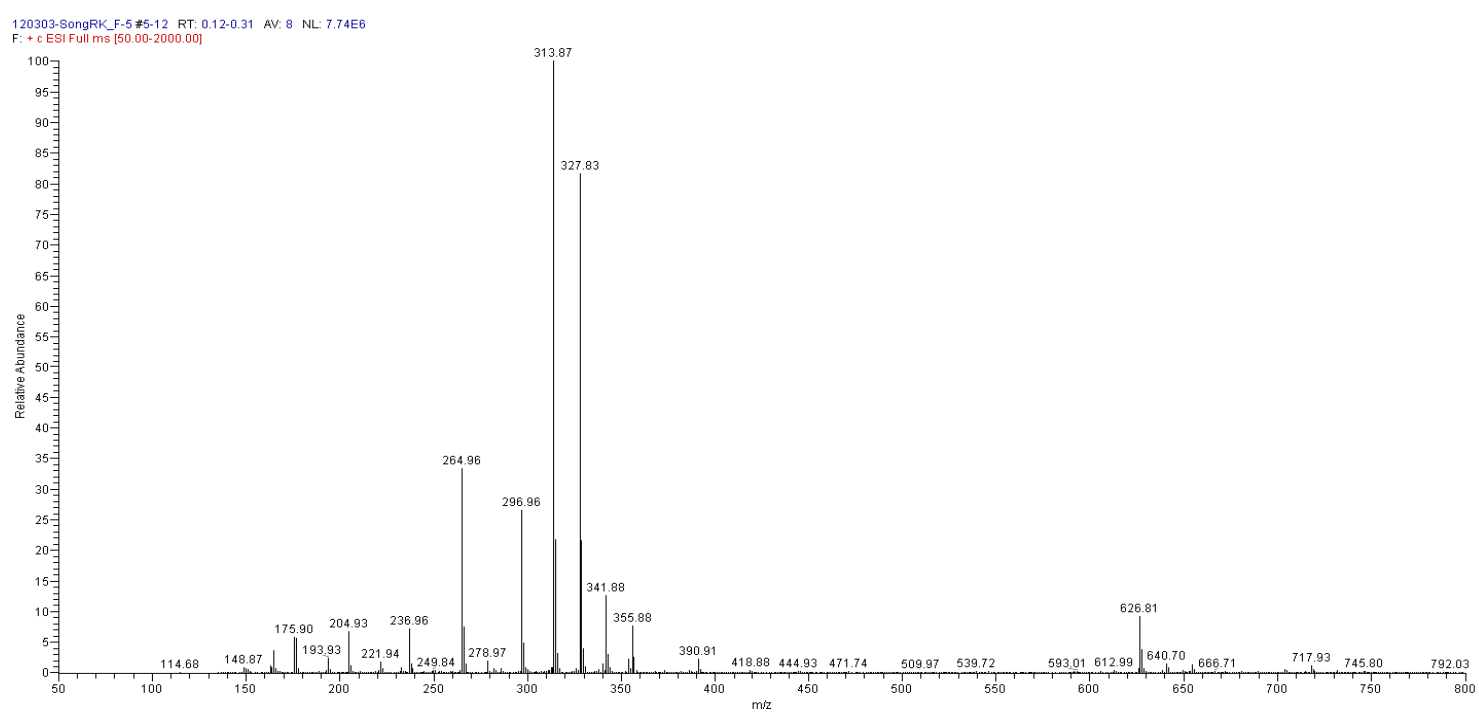


B

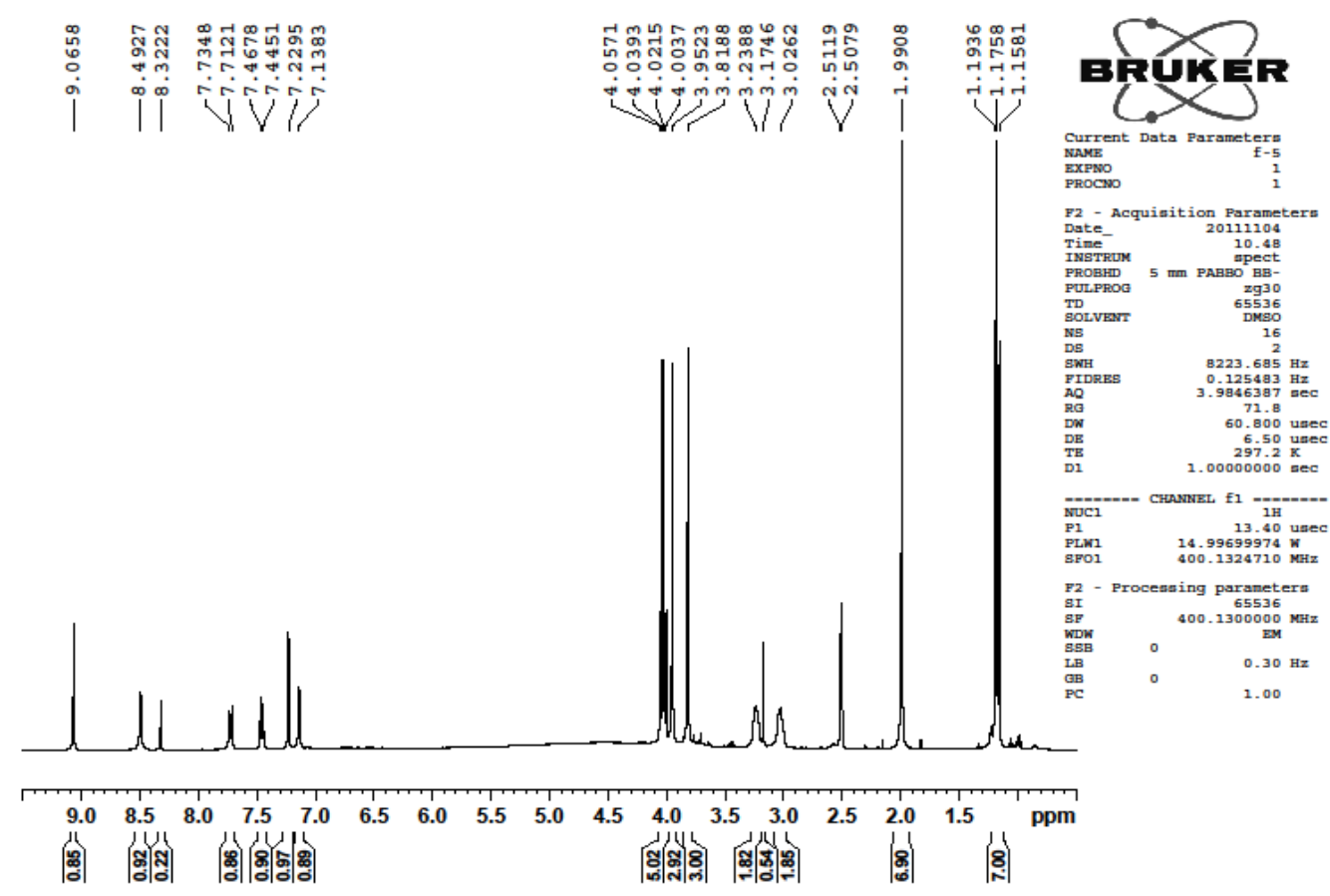

C

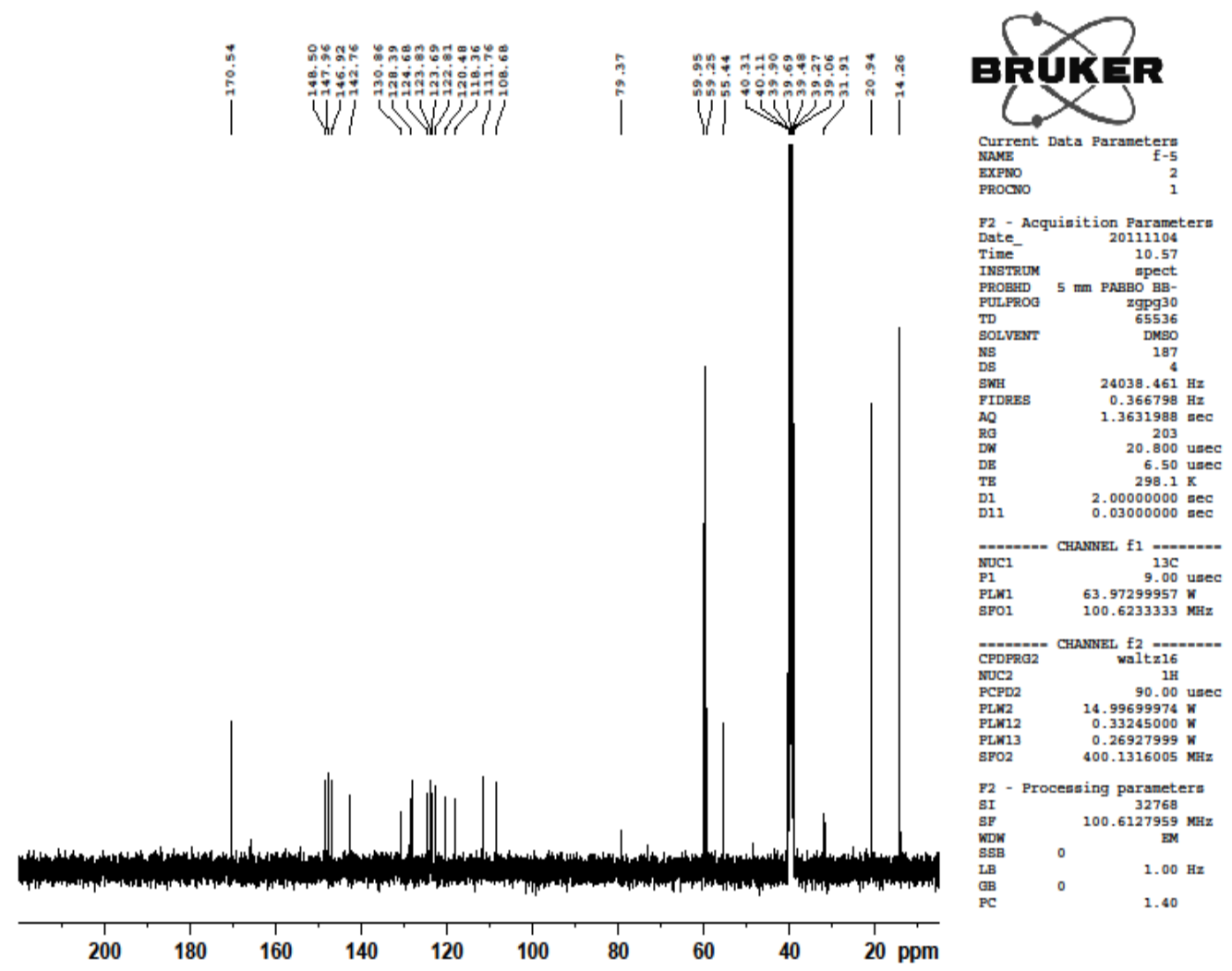

12. ESI-MS, ${ }^{1} \mathrm{H}-\mathrm{NMR}$ and ${ }^{13} \mathrm{C}$-NMR spectra of secolaurolitsine. (A) ESI-MS $[\mathrm{M}+\mathrm{H}]^{+}$of $\mathrm{s}$ ecolaurolitsine, (B) The ${ }^{1} \mathrm{H}-\mathrm{NMR}$ of secolaurolitsine, (C) The ${ }^{13} \mathrm{C}-\mathrm{NMR}$ of secolaurolitsine. 
Secolaurolitsine: Yellowish-brown amorphous powder $(\mathrm{MeOH})$, ESI-MS m/z: $313.9[\mathrm{M}+\mathrm{H}]^{+} .{ }^{1} \mathrm{H}-$ NMR (DMSO-d 6 , 400 MHz) $\delta_{\mathrm{H}}: 9.06(1 \mathrm{H}, \mathrm{s}, \mathrm{H}-5), 7.72(1 \mathrm{H}, \mathrm{d}, \mathrm{J}=9.08 \mathrm{~Hz}, \mathrm{H}-10), 7.45(1 \mathrm{H}, \mathrm{d}, \mathrm{J}$ $=9.08 \mathrm{~Hz}, \mathrm{H}-9), 7.23(1 \mathrm{H}, \mathrm{s}, \mathrm{H}-8), 7.14(1 \mathrm{H}, \mathrm{s}, \mathrm{H}-2), 3.95(3 \mathrm{H}, \mathrm{s}, 6-\mathrm{OMe}), 3.82(3 \mathrm{H}, \mathrm{s}, 4-\mathrm{OMe})$, $3.23(2 \mathrm{H}, \mathrm{m}, \mathrm{H}-11), 3.02(2 \mathrm{H}, \mathrm{m}, \mathrm{H}-12)$; ${ }^{13} \mathrm{C}-\mathrm{NMR}$ (DMSO-d $\left.6,100 \mathrm{MHz}\right) \delta_{\mathrm{C}}: 130.9(\mathrm{C}-1), 118.4(\mathrm{C}-$ 2), 148.5 (C-3), 142.8 (C-4), 124.7 (C-4a), 108.7 (C-5), 122.8 (C-5a), 148.0 (C-6), 146.9 (C-7), 111.8 (C-8), 128.4 (C-8a), 123.8 (C-9), 120.5 (C-10), 123.7 (C-10a), 31.9 (C-11), 40.3 (C-12), 59.3 (C4-OMe), 55.4 (C6-OMe), 32.6 (N-Me). Linderane: Colorless needle-like crystal (petroleum ether-ethyl acetate), ESI-MS m/z : $261.3[\mathrm{M}+\mathrm{H}\rceil^{+}$, combined with ${ }^{1} \mathrm{H}-\mathrm{NMR}\left(\mathrm{CDCl}_{3}, 500 \mathrm{MHz}\right)$ and ${ }^{13} \mathrm{C}$-NMR $\left(\mathrm{CDCl}_{3}, 125 \mathrm{MHz}\right)$ to determine the molecular formula: $\mathrm{C}_{15} \mathrm{H}_{16} \mathrm{O}_{4}$. Linderane was analysed by HPLC and TLC and co-chromatographed with the reference compound (linderane). 